\title{
Effects of experimental warming on small phytoplankton, bacteria and viruses in autumn in the Mediterranean coastal Thau Lagoon
}

\author{
Justine Courboulès 1 - Francesca Vidussi - Tanguy Soulié • Sébastien Mas • \\ David Pecqueur $\cdot$ Behzad Mostajir
}

Received: 16 October 2020/ Accepted: 9 March 2021/Published online: 27 March 2021

(C) The Author(s) 2021

\begin{abstract}
To investigate the responses of a natural microbial plankton community of coastal Mediterranean waters to warming, which are still poorly known, an in situ mesocosm experiment was carried out in Thau Lagoon during autumn 2018. Several microorganisms, including virio-, bacterio-, and phytoplankton $<10 \mu \mathrm{m}$ in size, were monitored daily and analysed using flow cytometry for 19 consecutive days in six mesocosms. Three mesocosms (control) had the same natural water temperature as the lagoon, and the
\end{abstract}

Handling Editor: Télesphore Sime-Ngando.

J. Courboulès $(\bowtie) \cdot$ F. Vidussi · T. Soulié · B. Mostajir MARBEC (Marine Biodiversity, Exploitation and Conservation), Univ Montpellier, CNRS, Ifremer, IRD, Montpellier, France

e-mail: justine.courboules@hotmail.fr

F. Vidussi

e-mail: francesca.vidussi@cnrs.fr

T. Soulié

e-mail: tanguy.soulie@umontpellier.fr

B. Mostajir

e-mail: behzad.mostajir@umontpellier.fr

S. Mas

MEDIMEER (Mediterranean Platform for Marine

Ecosystems Experimental Research), OSU OREME,

CNRS, Univ Montpellier, IRD, IRSTEA, Sète, France

e-mail: sebastien.mas1@umontpellier.fr other three were warmed by $+3{ }^{\circ} \mathrm{C}$ in relation to the control temperature. The cytometric analyses revealed an unexpected community dominated by picophytoplanktonic cells, including Prochlorococcus-like and Picochlorum-like cells, which had not previously been found in Thau Lagoon. The experimental warming treatment increased the abundances of nanophytoplankton, cyanobacteria, bacteria and viruses during the experiment and triggered earlier blooms of cyanobacteria and picoeukaryotes. Only the abundance of Picochlorum-like cells was significantly reduced under warmer conditions. The growth and

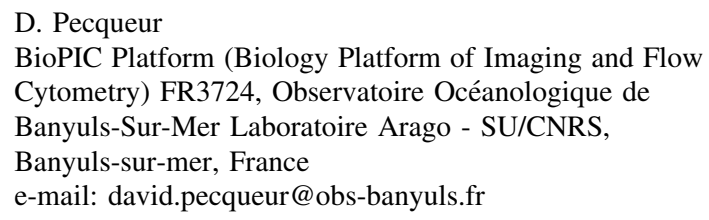

D. Pecqueur

BioPIC Platform (Biology Platform of Imaging and Flow Cytometry) FR3724, Observatoire Océanologique de Banyuls-Sur-Mer Laboratoire Arago - SU/CNRS, Banyuls-sur-mer, France e-mail: david.pecqueur@obs-banyuls.fr 
grazing rates of phytoplankton and bacterioplankton estimated on days 2 and 8 showed that warming enhanced the growth rates of most phytoplankton groups, while it reduced those of bacteria. Surprisingly, warming decreased grazing on phytoplankton and bacteria at the beginning of the experiment, while during the middle of the experiment it decreased the grazing on prokaryote only but increased it for eukaryotes. These results reveal that warming affected the Thau Lagoon plankton community from viruses to nanophytoplankton in fall, inducing changes in both dynamics and metabolic rates.

Keywords Pico- and nanophytoplankton . Bacterioplankton · Virus · Warming · In situ mesocosm $\cdot$ Thau lagoon

\section{Introduction}

Small phytoplankton, such as picophytoplankton and nanophytoplankton, and nonphotosynthetic prokaryotes, such as heterotrophic bacteria and archaea (hereafter referred to as bacteria only), are key components of microbial food webs (Pomeroy 1974; Azam et al. 1983; Mostajir et al. 2015a). They play an important role in the production of biomass, which is transferred by microzooplankton to higher trophic levels through the marine food web. Planktonic microorganisms are known to rapidly respond to environmental change (Hays et al. 2005). Notably, the warming of surface waters in relation to global changes is expected to affect marine microorganisms (Hays et al. 2005; IPCC 2014).

For instance, an experimental increase in water temperature was reported to affect the relative abundance of phytoplankton, favouring small phytoplankton cells in the community, such as pico- and nanophytoplankton (Pulina et al. 2016). Additionally, using in situ mesocosms, Vidussi et al. (2011) reported a significant decrease in bacterial abundance, noting that trophic cascades led to this change. Changes in planktonic microorganism abundance are mainly shaped by individual growth and mortality rates (Calbet and Landry 2004). In general, predation by grazers is the main contributor to the plankton mortality rate (Calbet and Landry 2004); thus, grazing activity is a driver of plankton dynamics. This is particularly relevant during blooms, as strong phytoplankton growth is considered to be the main driver of bloom initiation, while intense grazing is responsible for ending the bloom (Trombetta et al. 2019). However, viruses are also considered to affect the plankton mortality rate because they infect and lyse both bacteria and small phytoplankton (Fuhrman 1999), thus partially regulating their populations. Both growth and grazing rates are dependent on the temperature (Brown et al. 2004) and are thus sensitive to thermal variation. Therefore, these two rates are of prime interest when investigating the effects of experimental warming on microbial communities and organisms.

Studies have reported that even a slight elevation of the water temperature could enhance metabolic rates, such as phytoplankton and bacterial growth (Eppley 1972; Rivkin et al. 1996; Savage et al. 2004; Lewandowska et al. 2014). Similarly, other studies reported a positive effect of warming on the abundances of their corresponding grazers such as herbivorous and bacterivorous protists (Aberle et al. 2007; Rose and Caron 2007; Rose et al. 2009), thus potentially increasing grazing pressure. However, in a natural environment, the plankton growth rate is also affected by factors other than just temperature, including physical, chemical or biological forcings (i.e. light, nutrients, biological interactions). Therefore, increasing temperature does not systematically result in higher growth rates and then abundances, especially considering that warming can also affect these other forcings. Similarly, the stimulation of grazer activity under warming can also result in complex interactions, such as trophic cascades (Vidussi et al. 2011), leading to nonintuitive changes in grazing and mortality rates (Lewandowska et al. 2014). Thus, it is essential to study the responses of natural plankton communities to warming from very sensitive regions such as the Mediterranean Sea (Giorgi 2006; Lejeusne et al. 2010) or coastal waters (Rabalais et al. 2009). In this context, as studies of experimental warming are scarcer during fall, the autumnal in situ plankton community of the coastal Mediterranean Thau Lagoon was investigated. Thau Lagoon is connected by channels to the Mediterranean sea, and has a salinity varying from 29.6 to 40.8 (Derolez et al. 2020b). This lagoon is rather shallow, with a mean depth of $4 \mathrm{~m}$, and therefore is experiencing a great range of temperature variations through the 
year (Trombetta et al. 2019). Phytoplankton of Thau Lagoon is numerically dominated by a picophytoplankton community usually represented by prasinophytes (Bec et al. 2005). Cyanobacteria are generally observed in lesser abundances and only represented by the Synechococcus genus (Bec et al. 2005). The nanophytoplankton, which can dominate the phytoplankton community in term of biomass (Trombetta et al. 2019), is characterised by cryptophytes, chrysophytes and prymnesiophytes (Bec et al. 2011; Trombetta et al. 2019). Microphytoplankton are mainly represented by diatoms and dinoflagellates are generally less abundant, excepted during exceptional blooms (Derolez et al. 2020b). Thus, the phytoplankton community of Thau Lagoon is generally dominated by small phytoplankton (Trombetta et al. 2020). Bacteria are also highly abundant in the lagoon, their abundances ranging from 2.0 to $10.0 \times 10^{6}$ cells $\mathrm{cm}^{3}$ (Vidussi et al. 2011; Mostajir et al. 2015b). The grazers of these small phytoplankton and bacterial communities are mainly the heterotrophic flagellates and ciliates, as well as larger zooplankton such as rotifers, nauplii, and copepods (Lam-Hoai et al. 1997; Pecqueur et al. 2011).

To unravel how Thau Lagoon plankton community responds to warming, an in situ mesocosm study was conducted in this lagoon during the fall season. For this purpose, the water temperature of triplicate in situ mesocosms was increased by $3{ }^{\circ} \mathrm{C}$ (warmed mesocosms) compared to that of three other in situ mesocosms with natural lagoon water temperature (control mesocosms) to reproduce the predicted mean elevation in temperature expected for the Mediterranean region (IPCC 2007). To better reflect natural temperature changes over the course of the experiment, the warming procedure involved the continuous adjustment of the temperature of the warmed mesocosms by $+3{ }^{\circ} \mathrm{C}$ relative to that of the control mesocosms to follow natural nycthemeral and daily water temperature variations (Nouguier et al. 2007). The microbial community was sampled daily and analysed at fine cytometric resolution during the 19 days of the experiment, with the evaluation of viruses up to nanophytoplankton, including picoeukaryotes and cyanobacteria as well as bacteria. As a result, some unexpected picophytoplankton groups such as Prochlorococcus-like and Picochlorum-like cells were identified for the first time in Thau Lagoon. In addition, the growth and grazing rates of the phytoplanktonic and bacterial groups were estimated according to the 2-point dilution method two times during the experiment to determine the effect of an increase in water temperature on these specific rates. Finally, the biomass fluxes of the studied microbial components were estimated based on previous rate estimates to determine the effects of warming on biomass production and transfer through the system.

\section{Material and methods}

In situ mesocosm experiment

A mesocosm experiment was conducted from October 5 to 23,2018 , to assess the response of a natural autumnal plankton community to the mean warming expected to occur in the Mediterranean region by 2100 (IPCC 2007). Six mesocosms were immersed in the Mediterranean Thau Lagoon in southern France near the floating structure of the Mediterranean platform for Marine Ecosystems Experimental Research (MEDIMEER $43^{\circ} 24^{\prime} 00^{\prime \prime} \mathrm{N}, 3^{\circ} 36^{\prime} 00^{\prime \prime} \mathrm{E}$ ). The mesocosms were all simultaneously filled on October 4th with $2200 \mathrm{dm}^{3}$ of lagoon subsurface water that was beforehand filtered through $1000 \mu \mathrm{m}$ mesh and pooled in a tank on the MEDIMEER pontoon, before being distributed to the six mesocosms through 6 parallel pipes. The mesocosm bags were $1.2 \mathrm{~m}$ wide and $3 \mathrm{~m}$ long and installed on individual floating structures. Once filled, each mesocosm represented a 2-m water column immersed in the lagoon. The mesocosms were constructed with $200-\mu$ m-thick vinyl acetate mixedpolyethylene transparent film reinforced by nylon mesh (Insinööritoimisto Haikonen Ky). All bags were also covered by a transparent dome made of crystalclear polyvinyl chloride to prevent external inputs and transmitting $73 \%$ of the photosynthetically active radiation (PAR). Finally, a pump (Rule 360) was installed in each mesocosm to provide gentle mixing of the water column with a turnover time of $3.5 \mathrm{~d}^{-1}$.

Two treatments, each performed in triplicate, were applied in the present study: (1) the control, with a natural water temperature showing the same daily variations as the surrounding water in the lagoon, and (2) the warmed treatment, in which the temperature was elevated by $3{ }^{\circ} \mathrm{C}$ on the basis of model predictions generated by the Intergovernmental Panel on Climate Change (IPCC). On October 5th (day 0 of the 
experiment), the water temperature in the mesocosms under the warmed treatment was raised, after the samples were collected for that day, to reach a target of $+3{ }^{\circ} \mathrm{C}$ on October 6 th prior to sampling. This target temperature was then maintained until the end of the mesocosm experiment on October 23rd. The increase in water temperature was achieved by using a heating element (Galvatec) placed in each mesocosm in the warmed treatment to continuously adjust the temperature to $3{ }^{\circ} \mathrm{C}$ higher than that in the control to reflect natural water temperature conditions. Therefore, both the control and warmed mesocosms followed the same day/night and daily natural temperature fluctuations as the surrounding water in the lagoon but with a $3{ }^{\circ} \mathrm{C}$ increase in the warmed treatment (Nouguier et al. 2007).

To prevent accidental contamination and changes in the light conditions within the experimental mesocosms, two incubation mesocosms (1.2 m wide, $2 \mathrm{~m}$ long) were also immerged in the lagoon near the six experimental mesocosms to incubate the samples taken from the control and heated mesocosms for parallel experiments, such as dilution experiments and Winkler incubations.

Sampling and analyses of the physical and chemical properties of the experimental mesocosms

Daily sampling of all mesocosms was carried out every morning (09:00 h local time) from October 5th until October 23rd (representing day $0-18$ of the experiment). Temperature and salinity in all the mesocosms were monitored at the surface and at $1 \mathrm{~m}$ and $2 \mathrm{~m}$ depth using an EC300 (VWR) probe. A Niskin bottle $\left(5 \mathrm{dm}^{3}\right)$ was deployed inside each mesocosm at $1 \mathrm{~m}$ depth to collect water for the assessment of chemical variables. Samples for nutrient analyses $\left(50 \mathrm{~cm}^{3}\right)$ were carefully taken from the Niskin bottles with acid-washed polycarbonate bottles. The samples were then filtered on $0.45-\mu \mathrm{m}$ filters (Gelman) and stored at $-20{ }^{\circ} \mathrm{C}$. An automated colorimeter (Skalar Analytical) was used to determine the concentrations of nitrate $\left(\mathrm{NO}_{3}{ }^{-}\right)$, nitrite $\left(\mathrm{NO}_{2}{ }^{-}\right)$, orthophosphate $\left(\mathrm{PO}_{4}{ }^{3-}\right)$, and silicate $\left(\mathrm{SiO}_{2}\right)$.
Sampling, Chl- $a$ and flow cytometric plankton community analyses

All mesocosms were sampled daily (09:00 h) using two low-vacuum pumps connected in series (KNFN035AN.18) placed at $1 \mathrm{~m}$ depth in each mesocosm to fill acid-washed polycarbonate carboys $\left(20 \mathrm{dm}^{3}\right)$ for biological analyses. This notably included the samples for cytometry and chlorophyll $a(\mathrm{Chl}-a)$ analyses. For Chl- $a$ analyses, $0.5-1 \mathrm{dm}^{3}$ of the mesocosms water was daily filtered over Whatman glass-fibre filters (GF/F $25 \mathrm{~mm}$ diameter). Filters were frozen in liquid nitrogen and then stored at $-80{ }^{\circ} \mathrm{C}$ until analyses. Chl- $a$ concentrations were determined by high-performance liquid chromatography (HPLC, waters), using the method of Zapata et al. (2000), following the protocol of Vidussi et al. (2011).

Daily abundances of small phytoplankton, bacteria and viruses, from day 1 to day 18 of the experiment (October 5 and 23, respectively) were determined through flow cytometry (FCM) analyses. For this purpose, three samples of $1.5 \mathrm{~cm}^{3}$ were taken from the carboys to analyse separately the microorganisms. Phytoplankton and bacteria samples were fixed with $60 \mathrm{~mm}^{3}$ of glutaraldehyde (Grade 1), and viruses samples were fixed with $30 \mathrm{~mm}^{3}$ of glutaraldehyde (Grade 1 filtered over $0.02 \mu \mathrm{m}$ ), frozen in liquid nitrogen and stored at $-80{ }^{\circ} \mathrm{C}$. All phytoplankton groups were analysed simultaneously with a CytoFLEX flow cytometer (Beckman Coulter) for $3 \mathrm{~min}$ at high speed. Cyanobacteria were identified and counted on the basis of their relative forward scatter (FSC) and phycoerythrin and phycocyanin fluorescence (Fig. 1). Picoeukaryotes and nanophytoplankton were enumerated according to their FSC and Chl- $a$ fluorescence. All bacterial samples were analysed using a FACSCalibur flow cytometer (Becton-Dickinson) for $3 \mathrm{~min}$ at low speed after being stained with SYBR Green I (S7563, Invitrogen; 2\% final dilution) (Marie et al. 1997). Bacterial groups were identified and counted on the basis of their relative side scatter (SSC) and green fluorescence at $530 / 30 \mathrm{~nm}$. Viruses were analysed using a FACSCanto2 flow cytometer (Becton-Dickinson). Samples were stained with SYBR Green I (at a final dilution of $\left.0.5 \times 10^{-4}\right)$. Then, virus-like particles (hereafter referred to as viruses for simplification) were counted according to their SSC and green fluorescence at 530/30 nm (Brussaard 2004). Cytometry fluorescent beads (Polysciences, Inc.) of 1, 2, 6 

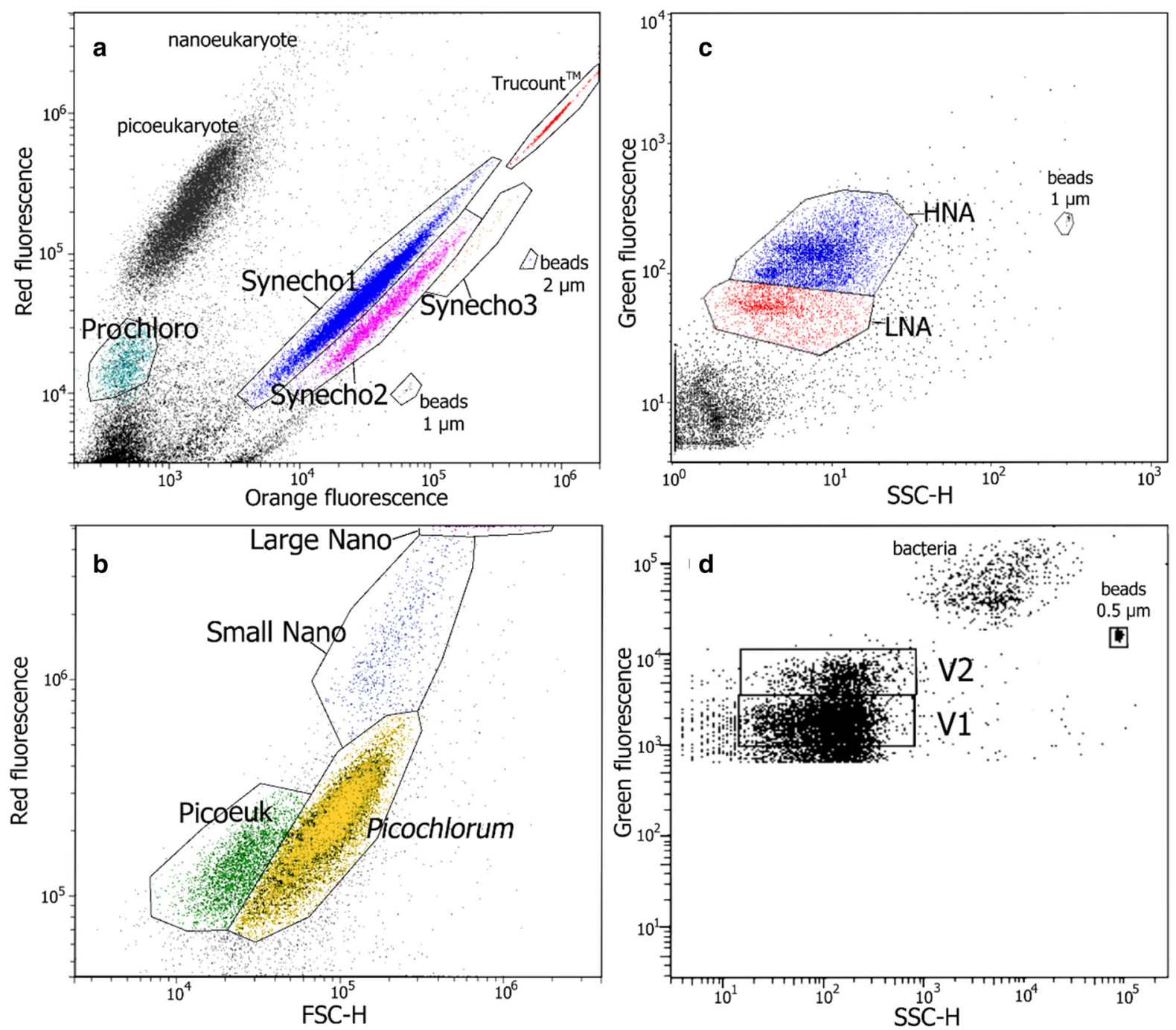

Fig. 1 The 12 different microbial groups (including viruses) identified by flow cytometry analyses. Among the cyanobacteria, there was one Prochlorococcus-like group, Prochloro, and three Synechococcus-like groups, Synecho1, Synecho2 and Synecho3 (a). There were also two picoeukaryote groups, Picoeuk and Picochlorum-like, (b) and two nanoeukaryote

and $10 \mu \mathrm{m}$ in diameter were used for phytoplankton sample analyses as internal cell size standards. This was also done for bacterial sample analyses with cytometry beads of 1 and $2 \mu \mathrm{m}$ in diameter and for virus samples with beads of $0.5 \mu \mathrm{m}$ in diameter (Polysciences, Inc.). In addition, Trucount ${ }^{\mathrm{TM}}$ beads were added to accurately estimate the volume of sample analysed (BD-Biosciences). On the basis of these FCM analyses, the concentration of each

groups: Small Nano and Large Nano (b). Two bacterial groups, HNA and LNA (c), were identified, as well as two virus groups named V1 and V2 (d). FSC: forward scatter signal linked to size and SSC: side scatter, signal linked to the cell structure and granulosity

plankton group identified was estimated daily (cells $\mathrm{cm}^{-3}$ ) from day 1 to day 18 of the experiment.

Analyses according to FCM revealed 8 phytoplanktonic, two bacterial and two viral groups. Three groups of phytoplankton had a similar fluorescence signature than Synechococcus cells. These Synechococcus-like cells were therefore called Synecho1, Synecho2 and Synecho3 (Fig. 1a). Another phytoplankton group had a fluorescence signature similar to Prochlorococcus cells (Chisholm 2017) and was thus 
identified as Prochlorococcus-like cells and labelled Prochloro. Two groups of picoeukaryotes were also identified, one group usually found in Thau Lagoon named Picoeuk and another with a fluorescence signature similar to that of Picochlorum (Fig. 1b). Finally, two groups of nanophytoplankton with size ranges of approximately between 2 and $6 \mu \mathrm{m}$ and between 6 and $10 \mu \mathrm{m}$ were also present and were labelled Small Nano and Large Nano, respectively (Fig. 1b). Heterotrophic bacteria were distinguished in two groups: low nucleic acid (LNA) and high nucleic acid (HNA) according to their low and high amounts of nucleic acid, respectively (Fig. 1c). Finally, two groups of viruses were identified and labelled V1 and V2 (Fig. 1d).

To estimate the carbon biomass $\left(\mu \mathrm{g} \mathrm{C} \mathrm{dm}{ }^{-3}\right)$ of each cytometric group, the phytoplankton and bacterial abundances were converted using previously published conversion factors: i.e. $20 \mathrm{fg} \mathrm{C} \mathrm{cell}^{-1}$ for bacteria (Sime-Ngando et al. 1995), $210 \mathrm{fg} \mathrm{C}$ cell $^{-1}$ for Synechococcus (Kemp et al. 1993), and $45 \mathrm{fg} \mathrm{C}$ cell $^{-1}$ for Prochlorococcus (Bertilsson et al. 2003). For the other phytoplankton groups, carbon biomass was estimated based on their relative volume by assuming a spherical shape for all groups and considering a conversion factor of $0.22 \mathrm{pg} \mathrm{C} \mu \mathrm{m}^{-3}$ (Kemp et al. 1993). For this calculation, we estimated the approximate diameter of cells within a group by comparing their average forward scatter signal (approximate size) with that of the previously mentioned standard beads, assigning 1.0 and $1.5 \mu \mathrm{m}$ diameter to Picoeuk and Picochlorum, respectively, and 4 and $8 \mu \mathrm{m}$ to Small and Large Nano, respectively (Trombetta et al. 2019).

Growth and grazing rate estimation

for phytoplankton and bacteria

The cell growth and grazing rates for each group in each mesocosm were estimated at the beginning (day 2) and halfway (day 8) through the experiment. For this purpose, a modified version of the original dilution method of Landry and Hassett (1982), using only 2 levels of dilution: $100 \%$ and $10 \%$, was performed (Worden and Binder 2003; Strom and Fredrickson 2008; Menden-Deuer and Fredrickson 2010). After the daily sampling was performed, $20 \mathrm{dm}^{3}$ of water was gently collected from every mesocosm using a vacuum pump and filtered through $200 \mu \mathrm{m}$ mesh.
Triplicate Whirlpack bags $\left(2 \mathrm{dm}^{3}\right)$ were then filled with this filtered sample to constitute the level of $100 \%$. To constitute the triplicate bags $\left(2 \mathrm{dm}^{3}\right)$ of the $10 \%$ sample dilution, some of the filtered sample was gravity filtered at 0.8 and $0.2 \mu \mathrm{m}$ (Whatman Polycap TC Filter Capsule 0.8/0.2 $\mu \mathrm{m}$ ) and used to dilute the previously filtered water to $10 \%$. An additional set of triplicate of the undiluted $(100 \%)$ filtered water was prepared and enriched with inorganic nutrients (final concentration of $4 \mu \mathrm{M} \mathrm{N}, 0.25 \mu \mathrm{M} \mathrm{P}$, and $4 \mu \mathrm{M} \mathrm{Si}$ ). This $100 \%$ + nutrient (NUT) addition allowed us to determine whether nutrients were limited during the dilution experiments. All bags were then placed in the incubation mesocosms for $24 \mathrm{~h}$.

To determine the plankton abundances, two samples of $1.5 \mathrm{~cm}^{3}$ were taken for FCM analyses from all $100 \%$ bags before incubation (T0) and from bags at all dilution levels $(10 \%, 100 \%, 100 \%+$ NUT) after incubation (T24).

Instantaneous growth rates $\left(k, \mathrm{~d}^{-1}\right)$ were then calculated for each group at every level of dilution following Eq. (1) (Landry and Hassett 1982):

$k=\frac{1}{t} \times \ln \left(\frac{\mathrm{NT} 24}{\mathrm{NT} 0}\right)$

where $k$ is the instantaneous growth rate $\left(\mathrm{d}^{-1}\right)$ estimated from the initial and final plankton abundances, NT0 and NT24, respectively, during the incubation time, $t(\mathrm{~d})$. The initial (T0) plankton abundance at the $10 \%$ level was calculated from the plankton abundances quantified at the $100 \%$ level before incubation. The final growth rate was determined as the instantaneous growth rate at $10 \%$, and the grazing rate was calculated as the difference in the instantaneous growth rate at 10 and $100 \%$ (Worden and Binder 2003; Strom and Fredrickson 2008; Menden-Deuer and Fredrickson 2010; Chen 2015).

In particular cases, negative growth and positive grazing rates (inverted slope) were considered as 0.01 $\mathrm{d}^{-1}$ growth and $0.00 \mathrm{~d}^{-1}$ grazing, respectively (Calbet and Landry 2004).

It should be noted that the growth rate estimated in the present study is not characterised as the maximal growth rate estimated according to the original method described by Landry and Hassett (1982). Indeed, the growth rates presently reported were not amended in the case of nutrient limitation; however, these specific cases are discussed, as they potentially occurred in the 
mesocosms and were also under the effect of warming. Thus, the growth rates estimated in the present investigation represent a rate closer to what occurred in the mesocosms, encompassing the potential nutrient limitations that affected the natural plankton community.

\section{Statistical analyses}

To evaluate the effect of warming throughout the experiment, mean abundance time series were compared between the treatments using variance analyses of repeated measures (RM-ANOVA, $p$ value $<0.05$ ). More precisely, comparisons were performed when the warmed mesocosms reached the target temperature during the experiment (from day 1 to 18 ). Due to the observation of specific abundance trends, additional RM-ANOVAs were also performed over different periods for certain groups: from day 3 to 9 and 11 to 15 for Synecho1; from day 1 to 7 and 8 to 18 for Picoeuk; and from day 3 to 9 and 11 to 17 for HNA. Normality and homogeneity of variance were assessed, and data were occasionally log transformed to meet these assumptions. When the assumption of normality could not be met, a Kruskal-Wallis test was performed instead. Average growth and grazing rates were also compared between treatments. However, as the sample size was not sufficient to accurately verify normality and variance homogeneity, comparisons between treatments were performed using the Kruskal-Wallis test ( $p$ value $<0.05$ ). Similarly, to determine whether inorganic nutrient addition had any significant effect on the various cytometric groups, instantaneous growth rates estimated for the $100 \%$ and $100 \%$ + NUT treatments were compared with the Kruskal-Wallis test. All data management and statistical analyses were performed using $\mathrm{R}$ software ( $\mathrm{R}$ Project version 3.6).

\section{Results}

Temperature, nutrients and chlorophyll-a variability in the mesocosms

The average temperature across the triplicate control mesocosms decreased from 18.9 to $18.3{ }^{\circ} \mathrm{C}$ from day 1 to 4 and then increased, reaching $19.4{ }^{\circ} \mathrm{C}$ on day 9 (Fig. 2a). The average temperature then declined to
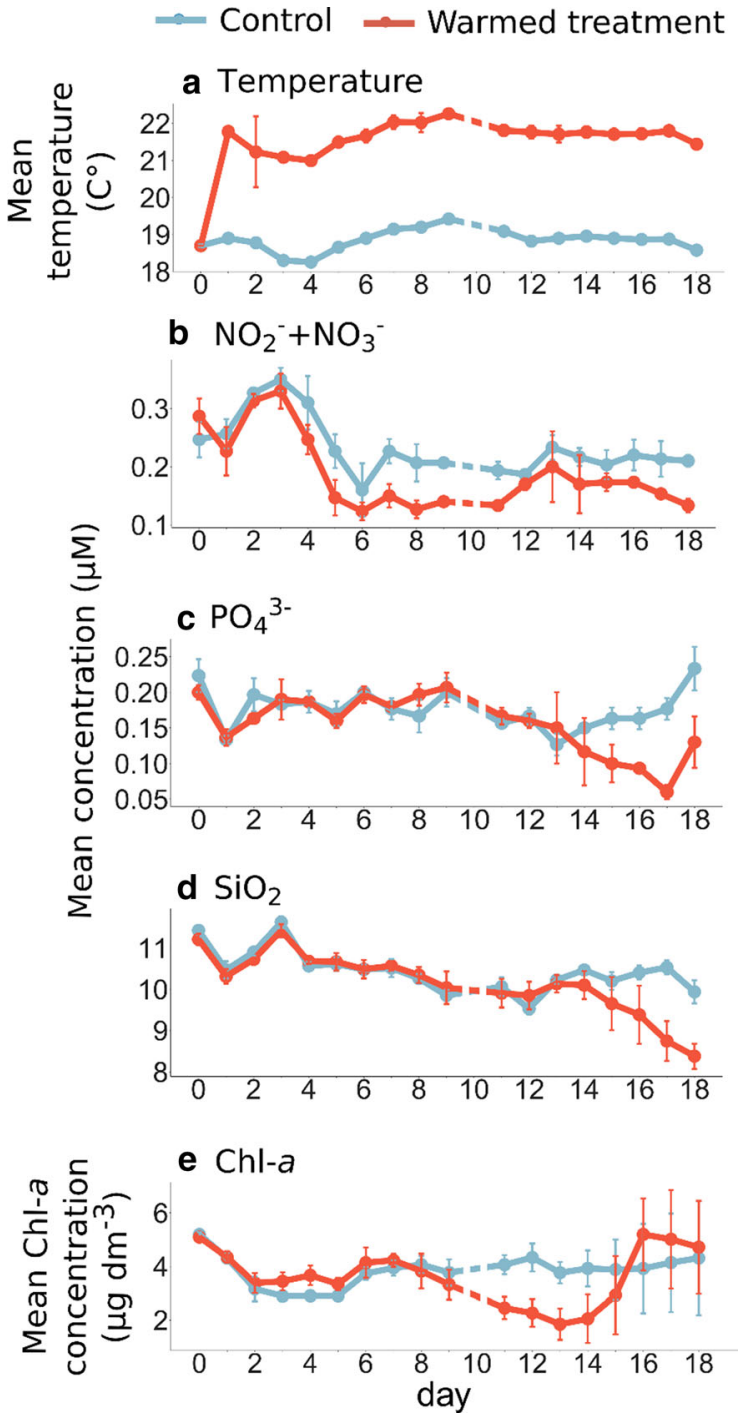

Fig. 2 Daily average temperature (a), and concentrations of nitrates + nitrites $\left(\mathbf{b}, \mathrm{NO}_{2}{ }^{-}, \mathrm{NO}_{3}\right)$, orthophosphates $\left(\mathbf{c}, \mathrm{PO}_{4}{ }^{3-}\right)$, silicates $\left(\mathbf{d}, \mathrm{SiO}_{2}\right)$ and chlorophyll- $a(\mathrm{Chl}-a, \mathrm{e})$ in the control (blue) and warmed mesocosms (red). Error bars represent the standard error of the mean. Dotted lines represent the missing data for day 10 due to bad meteorological conditions

$18.6^{\circ} \mathrm{C}$ by the end of the experiment (day 18). In the warmed treatment, the water temperature was successfully raised by an average of $2.8^{\circ} \mathrm{C}\left( \pm 0.11{ }^{\circ} \mathrm{C}\right.$, $n=54$ ) over the course of the experiment (from day 1 to 18 ).

The mean concentrations of nitrates + nitrites $\left(\mathrm{NO}_{2}{ }^{-}+\mathrm{NO}_{3}{ }^{-}\right)$and orthophosphate $\left(\mathrm{PO}_{4}{ }^{3-}\right)$ were rather low during the experiment in the control mesocosms, reaching averages of $0.23( \pm 0.02$, 
$n=57)$ and $0.18( \pm 0.01, n=57) \mu \mathrm{M}$, respectively (Fig. 2b, c). Silicates $\left(\mathrm{SiO}_{2}\right)$ occurred in relatively high concentrations, in contrast, reaching an average of 10.45 ( $\pm 0.15, n=57) \mu \mathrm{M}$ in the control (Fig. 2d). The nutrient concentrations were significantly lower under warming than in the control mesocosms. Notably, the mean $\mathrm{NO}_{2}{ }^{-}+\mathrm{NO}_{3}{ }^{-}$concentration was $0.19( \pm 0.02, n=57) \mu \mathrm{M}$ on average over the course of the experiment in the warmed treatment. The orthophosphate and silicate concentrations were rather similar within the treatments from day 0 to 13 , and then they decreased in average under warming, reaching the lowest concentrations of $0.06 \mu \mathrm{M}$ for orthophosphates on day 17 and $8.38 \mu \mathrm{M}$ for silicates on day 18.

Chl- $a$ concentrations were high during the whole experiment, attaining in average $3.84( \pm 0.62, n=57)$ $\mu \mathrm{g} \mathrm{dm}{ }^{-3}$ in the control (Fig. 2e). In the warmed treatment, Chl- $a$ concentrations were similar to the control until day 7 , after which it strongly decreased by $51 \%$ compared to the control, attaining $1.85 \mu \mathrm{g} \mathrm{dm}^{-3}$ on day 13. After day 13 , concentrations in the warmed treatment increased, reaching $5.19 \mu \mathrm{g} \mathrm{dm}^{-3}$ on day 16 , and even overcame concentrations in the control (Fig. 2e).

Phytoplankton, bacteria and virus dynamics in the control mesocosms

Among the different evaluated phytoplankton groups, Synecho1 and Picochlorum were the most abundant, reaching $2.1 \times 10^{5}\left( \pm 0.9 \times 10^{5}, n=57\right)$ and $7.8 \times 10^{4}\left( \pm 2.1 \times 10^{4}, n=57\right)$ cells $\mathrm{cm}^{-3}$ on average, respectively. Then, there were Synecho2, Prochloro and Picoeuk which abundances, ranging from $1.3 \times 10^{4}\left( \pm 0.8 \times 10^{4}, n=57\right)$ to $2.6 \times 10^{4}$ $\left( \pm 4.4 \times 10^{4}, n=57\right)$ cells $\mathrm{cm}^{-3}$ on average. Other phytoplankton groups were the least abundant ranging from $230( \pm 70, n=57)$ to $5.8 \times 10^{3}\left( \pm 4.4 \times 10^{3}\right.$, $n=57)$ cells $\mathrm{cm}^{-3}$ on average. The experiment began with high abundances of all phytoplanktonic groups in all mesocosms (Fig. 3). Then, the abundances generally decreased over time among all groups except for Synecho1 and Picoeuk, which abundances increased and then decreased, forming the bell-shape dynamic indicating a bloom, from day 3 to 11 and from day 6 to 8, respectively (Fig. 3a1, b1). In particular, Synecho1 reached a peak in abundance of $3.5 \times 10^{5}$ cells cm$^{-3}$ on day 11, while Picoeuk reached a maximal abundance of $1.9 \times 10^{4}$ cells $\mathrm{cm}^{-3}$ on day 8 .

Among the two bacterial groups, HNA had the highest abundance, with $3.0 \times 10^{6}\left( \pm 0.8 \times 10^{6}\right.$, $n=57$ ) cells $\mathrm{cm}^{-3}$ on average during the whole experiment, while LNA abundances were lower at $1.3 \times 10^{6}\left( \pm 0.9 \times 10^{6}, n=57\right)$ cells $\mathrm{cm}^{-3}$. Bacteria followed the general trend of that of phytoplankton, with initial high abundances followed by a general decrease (Fig. 3c). However, HNA abundance also followed the same trend as the blooming Synecho1, with an increase from day 3 , reaching a maximum abundance of $3.7 \times 10^{6}$ cells $\mathrm{cm}^{-3}$ on day 13 , followed by a decrease. On the other hand, LNA abundances decreased at the beginning of the experiment and then remained at approximately $8.8 \times 10^{5}$ $\left( \pm 1.2 \times 10^{5}, n=57\right)$ cells $\mathrm{cm}^{-3}$ on average until the end of the experiment.

In contrast, virus abundances generally increased from the beginning to the end of the experiment from $3.5 \times 10^{7}$ (day 0) to $5.9 \times 10^{7}$ viruses $\mathrm{cm}^{-3}$ (day 18 ) for $\mathrm{V} 1$, and from $7.8 \times 10^{6}$ (day 0 ) to $1.1 \times 10^{7}$ viruses $\mathrm{cm}^{-3}$ (day 18) for V2 (Fig. 3d).

Effects of warming on the dynamics and abundances of phytoplankton, bacteria and viruses in the heated mesocosms

In general, warming significantly increased the abundances of most cyanobacteria and nanophytoplankton groups by $21-264 \%$ on average (Fig. 4 , Table 1 ). In addition, for Picoeuk and Synecho1, which bloomed, abundances were significantly higher in the warmed treatment than in the control prior to reaching their maximal abundances, which occurred 2-3 days earlier under warming than under control conditions. Afterward, the abundances of these two groups decreased sharply and were then significantly lower in the warmed treatment than in the control (Fig. 4, Table 1). A notable exception to these results was observed for Picochlorum, which was the only phytoplanktonic group showing a significant decrease in abundance with warming, with $25 \%$ lower abundances in the warmed treatment than in the control. More specifically, the abundances of Picochlorum were similar in the two treatments until day 5 but then decreased in the warmed mesocosms until the end of the experiment.

Bacteria showed a similar response to warming to that of the phytoplankton groups (Fig. 4, Table 1). 

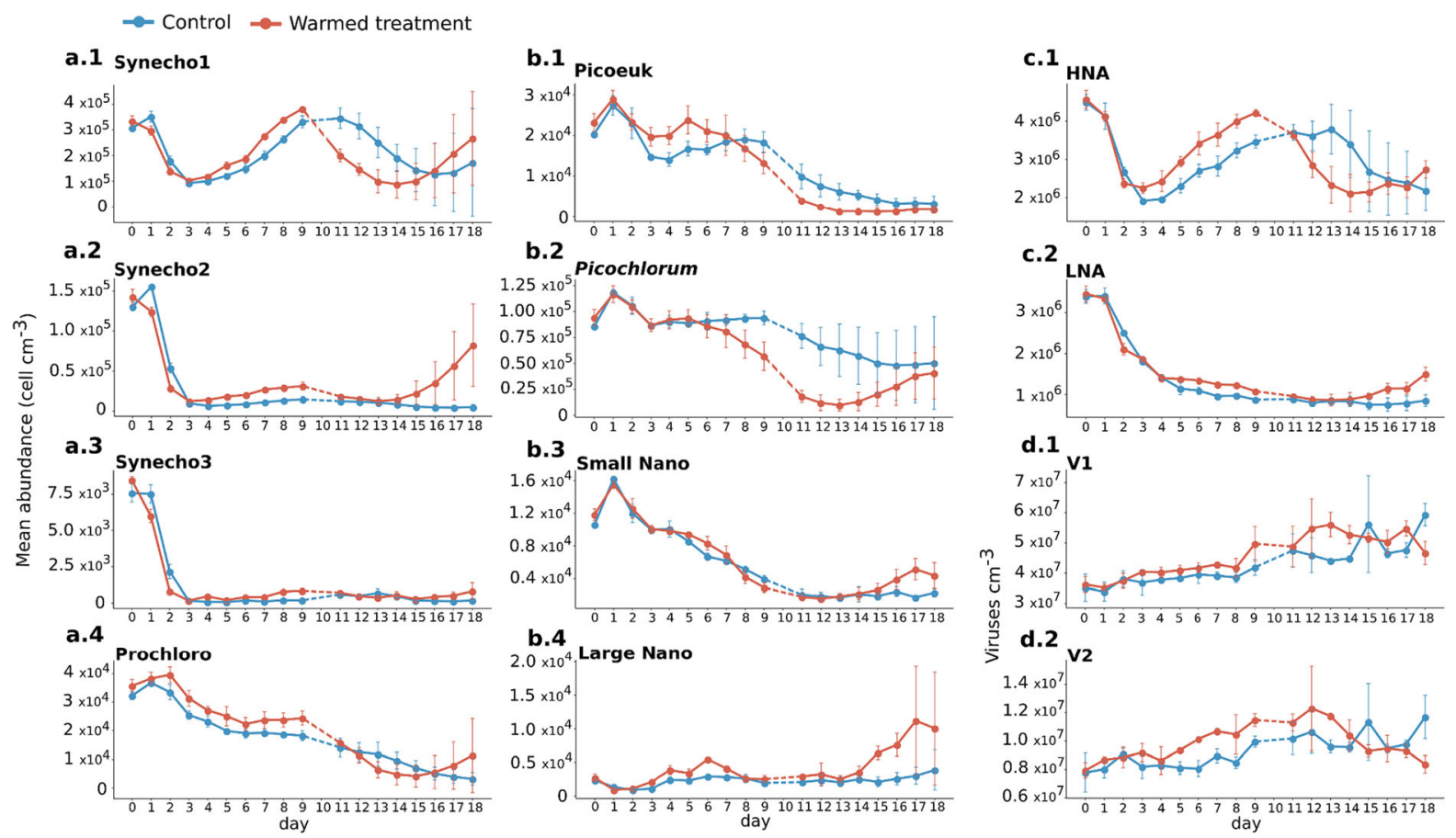

Fig. 3 Daily mean abundances of cyanobacteria (a.1, 4), picophytoeukaryotes (b.1, 2), nanophytoplankton (b.3, 4), bacteria $(\mathbf{c . 1}, 2)$ expressed as cells $\mathrm{cm}^{-3}, \pm$ standard deviations, and mean abundances of viruses $(\mathbf{d . 1}, 2)$ expressed as viruses

LNA abundances were consistently higher by $19 \%$ on average in the warmed treatment than in the control. Similar to those of Synecho1, HNA abundances were significantly higher in the warmed treatment than in the control from day 3 to 9 , before reaching a maximal abundance of $15 \%$ higher 4 days earlier than in the control. Afterward, the HNA abundances also sharply decreased and were significantly lower in the warmed treatment than in the control from day 11 to 17.

Similar to the bacteria, the V1 and V2 groups were $7 \%$ more abundant on average in the warmed treatment than in the control (Fig. 4, Table 1).

\section{Effects of warming on carbon biomass repartition}

In the control mesocosms, the phytoplankton groups $(<10 \mu \mathrm{m})$ were the main contributors to the daily carbon biomass (derived from abundances), representing $60 \%$ of the estimated carbon biomass on average (phytoplankton $<10 \mu \mathrm{m}+$ bacteria) and ranging from 78 to $287 \mu \mathrm{g} \mathrm{C} \mathrm{dm}^{-3}$ (Fig. 4a). Bacteria represented $40 \%$ of the estimated carbon biomass, $\mathrm{cm}^{-3}, \pm$ standard deviations in the controls (blue) and warmed (red) treatments. Dotted lines represent the missing data from day 10 due to bad meteorological conditions

ranging from 61 to $158 \mu \mathrm{g} \mathrm{C} \mathrm{dm}^{-3}$. The total phytoplankton $(<10 \mu \mathrm{m})$ and bacterial carbon biomass estimated in the control mesocosms was the highest at the beginning of the experiment (day 1), reaching $438 \mu \mathrm{g} \mathrm{C} \mathrm{dm}^{-3}$. Then, the estimated carbon biomass decreased from day 1 to day 3 before increasing and reaching a second maximum of $240 \mu \mathrm{g} \mathrm{C} \mathrm{dm}^{-3}$ on day 9. The carbon biomass then decreased to $142 \mu \mathrm{g} \mathrm{C} \mathrm{dm}^{-3}$ on day 17 (the end of the experiment) (Fig. 4a).

In the warmed mesocosms, phytoplankton $(<10 \mu \mathrm{m})$ also represented $60 \%$ of the estimated carbon biomass, while bacteria represented $40 \%$. However, after the initial high carbon biomass value in the warmed treatment, the maximal estimated carbon biomass was $13 \%$ higher than that in the control and occurred two days earlier, reaching $271 \mu \mathrm{g}$ $\mathrm{C} \mathrm{dm}{ }^{-3}$ on day 7 (Fig. 4b). Finally, the summed daily phytoplankton and bacterial carbon biomass values were only 6 and $4 \%$ higher, respectively, in the warmed treatment than in the control treatment. 


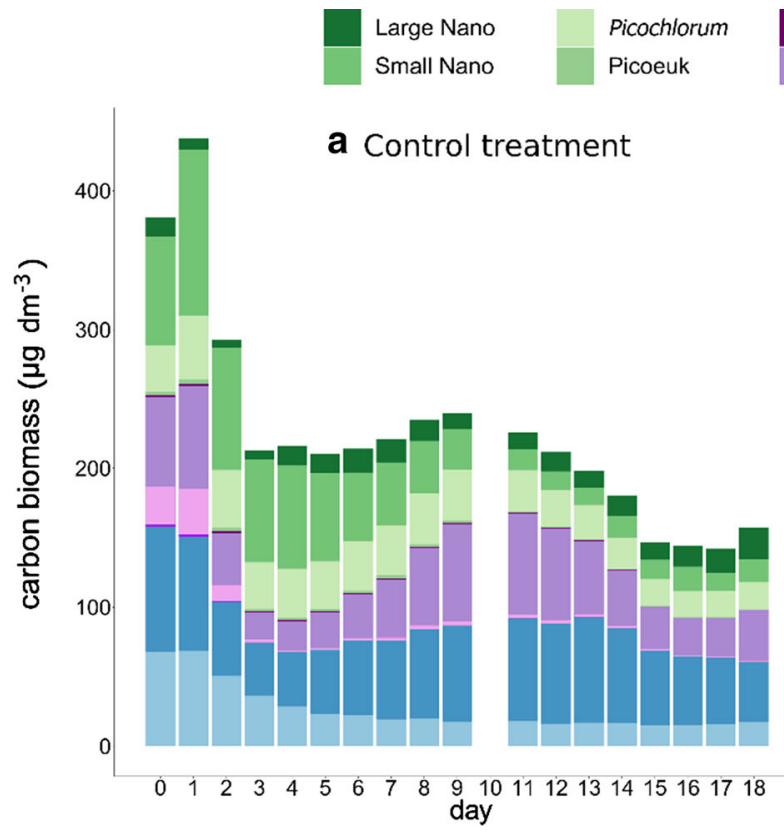

Fig. 4 Histograms of the cumulative daily average carbon biomass ( $\mu \mathrm{g} \mathrm{C} \mathrm{dm}^{-3}$ ) estimated for different phytoplankton $(<10 \mu \mathrm{m})$ and bacterial groups in the triplicate control (a) and triplicate warmed (b) mesocosms. Bacterial groups (LNA and

Phytoplankton and bacterial growth and grazing rates

Growth and grazing rates were estimated for the phytoplankton and bacterial groups twice over the course of the experiment, at the beginning (day 2) and in the middle of the experiment (day 8) during the period when Synechol exhibited a bloom and the HNA bacterial group reached a high abundance. In the control on day 2, Large Nano had the highest growth rate of $1.16 \mathrm{~d}^{-1}$, followed by bacterial groups, with growth rates ranging from 0.65 to $0.77 \mathrm{~d}^{-1}$, and Small Nano, with a growth rate of $0.35 \mathrm{~d}^{-1}$ (Fig. 5a). In contrast, the other phytoplankton groups had relatively low growth rates, ranging from 0.01 to $0.07 \mathrm{~d}^{-1}$. On day 8, the Large Nano and both the HNA and LNA bacterial groups still showed high growth rates of 0.61 , 0.65 and $0.79 \mathrm{~d}^{-1}$, respectively, and Synecho3 reached a high growth rate of $0.50 \mathrm{~d}^{-1}$ (Fig. 5b).

Warming generally enhanced the growth rates of the phytoplankton. Both picophytoplankton groups of Picoeuk and Picochlorum, in particular, showed growth rates significantly higher in the warmed treatment than in the control, with an increase of approximately $150 \%$, on day 2 (Fig. 5a, Table 2).

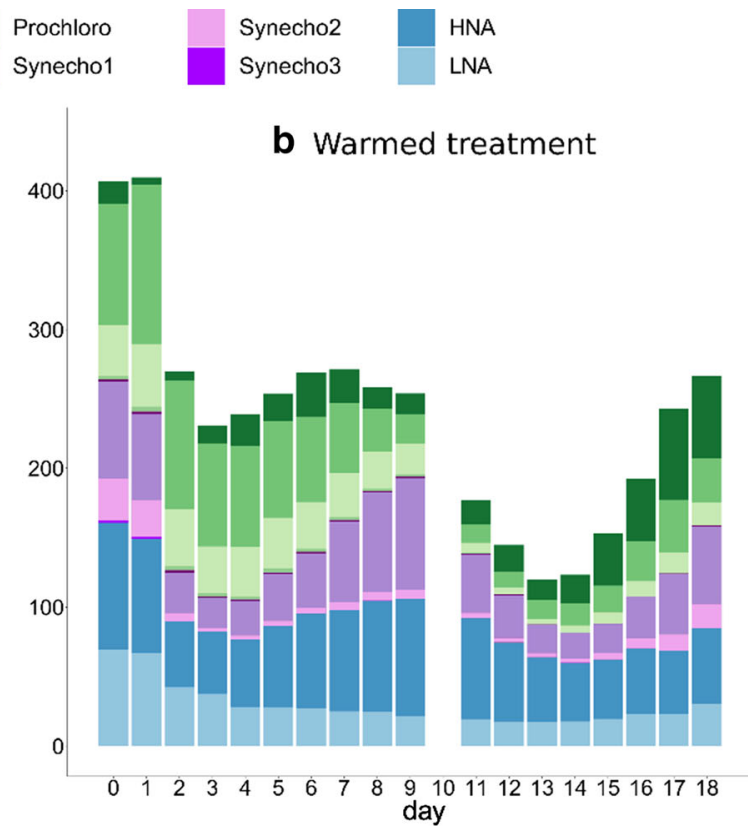

HNA) are represented in shades of blue, cyanobacteria (Prochloro, Synecho1, Synecho2, Synecho3) are represented in purple, and phytoeukaryotes (Picoeuk, Picochlorum, Small Nano and Large Nano) are represented in green

Similarly, on day 8 , the growth rates of most phytoplankton groups were higher in the warmed treatment, especially among Prochloro, Picoeuk and Small Nano, whose growth rates were significantly higher by $150-750 \%$ than in the control (Fig. 5b, Table 2). In contrast to this general trend, warming appeared to have a negative effect on bacterial group growth rates, with consistently negative effects on LNA and HNA, showing a higher growth rate only once at the beginning of the experiment. In fact, on day 2 , the HNA growth rate was significantly higher by $29 \%$ in the warmed treatment than in the control, while that of LNA was $14 \%$ lower. Afterwards, on day 8 , both LNA and HNA growth rates were lower by 42 and $17 \%$, respectively, under warmer conditions than in the control treatment (Fig. 5, Table 2).

To further analyse the growth rate response of the cytometric groups, nutrients were added to determine whether any nutrient limitation occurred during the dilution experiment (Fig. 6). However, among those of the 10 studied groups, only the instantaneous growth rate of Large Nano was consistently significantly enhanced by the addition of nutrients regardless of the treatment (control or warmed) on days 2 and 8 , with 
Table 1 Summary of the $p$ values from the RMANOVA comparing Chl$a$ concentrations, nutrient concentrations and cell abundances in each group resolved by flow cytometry over different periods during the experiment

$p$ values smaller than or equal to 0.05 were considered significant and are highlighted in bold characters

\begin{tabular}{|c|c|c|c|}
\hline \multicolumn{2}{|l|}{ Variables } & \multirow{2}{*}{$\begin{array}{l}\text { Periods } \\
1-18\end{array}$} & \multirow{2}{*}{$\frac{p \text { values }}{0.39}$} \\
\hline $\begin{array}{l}\text { Chl- } a \text { concentrations } \\
\left(\mu \mathrm{g} \mathrm{dm}^{-3}\right)\end{array}$ & & & \\
\hline Nutrient concentrations & $\mathrm{NO}_{2}^{-}+\mathrm{NO}_{3}^{-}$ & $1-18$ & $8.5 \times 10^{-5}$ \\
\hline$(\mu \mathrm{M})$ & $\mathrm{PO}_{4}{ }^{3-}$ & $1-18$ & $3.9 \times 10^{-4}$ \\
\hline & $\mathrm{SiO}_{2}$ & $1-18$ & $2.1 \times 10^{-4}$ \\
\hline \multirow{16}{*}{$\begin{array}{l}\text { Cell group abundance } \\
\left(\text { cell } \mathrm{cm}^{-3}\right)\end{array}$} & Synecho1 & $1-18$ & 0.56 \\
\hline & Synecho1 & $3-9$ & $4.1 \times 10^{-3}$ \\
\hline & Synecho1 & $11-15$ & $5.5 \times 10^{-3}$ \\
\hline & Synecho2 & $1-18$ & $7.5 \times 10^{-8}$ \\
\hline & Synecho3 & $1-18$ & $6.5 \times 10^{-3}$ \\
\hline & Prochloro & $1-18$ & $2.2 \times 10^{-2}$ \\
\hline & Picoeuk & $1-18$ & 0.59 \\
\hline & Picoeuk & $1-7$ & $8.5 \times 10^{-3}$ \\
\hline & Picoeuk & $8-18$ & $2.0 \times 10^{-4}$ \\
\hline & Picochlorum & $1-18$ & $1.1 \times 10^{-3}$ \\
\hline & Small Nano & $1-18$ & 0.1 \\
\hline & Large Nano & $1-18$ & $3.0 \times 10^{-4}$ \\
\hline & LNA & $1-18$ & 0.01 \\
\hline & HNA & $1-18$ & 0.89 \\
\hline & HNA & $3-9$ & $7.5 \times 10^{-5}$ \\
\hline & HNA & $11-17$ & $\mathbf{0 . 0 3}$ \\
\hline Viruses group abundance & V1 & $1-18$ & 0.02 \\
\hline$\left(\right.$ viruses $\mathrm{cm}^{-3}$ ) & $\mathrm{V} 2$ & $1-18$ & 0.11 \\
\hline
\end{tabular}

instantaneous growth rates increasing by 101-224\% upon nutrient addition depending on the treatment and the day. Additionally, only three other groups (Small Nano, Synecho3 and HNA) showed significantly higher rates under nutrient enrichment than without on day 8 and only in the warmed treatment.

The analyses of grazing mortality rates in the control revealed that on day 2 , the grazing mortality rates were particularly high for the Synechococcuslike groups, with the rates for Synecho3 and Synecho2 reaching 1.40 and $1.26 \mathrm{~d}^{-1}$, respectively (Fig. 5, Table 2). The grazing mortality rates for the other phytoplankton groups were lower, ranging from 0.18 to $0.62 \mathrm{~d}^{-1}$. Bacterial grazing mortality rates were particularly high on day 2 , reaching 1.19 and $1.09 \mathrm{~d}^{-1}$ for LNA and HNA, respectively (Fig. 5, Table 2). On day 8 , the grazing mortality rates for Synecho3 and bacterial groups HNA and LNA decreased by approximately two times, although Synecho3 still showed the highest rates among the phytoplankton groups, with a value of $0.60 \mathrm{~d}^{-1}$, while the rates of the other phytoplankton groups ranged between 0.05 and 0.44 $\mathrm{d}^{-1}$.

In the warmed treatment, the grazing mortality rates for most phytoplanktonic groups were lower than those in the control on day 2 , with values decreasing by $13-57 \%$ (Fig. 5c). This difference was significant for all Synechococcus-like groups (Synecho1, 2, and 3 ) and Picoeuk (Table 2). The grazing mortality rates for cyanobacteria (Synecho1, 2, and 3 and Prochloro) were still lower on day 8 , with values that were $30-69 \%$ lower under warmer conditions than in the control and being significantly lower for Synechol and Synecho2 (Table 2). Additionally, the grazing mortality rates for both HNA and LNA cell groups were significantly lower by $11-55 \%$ in the warmed treatment than in the control on both day 2 and day 8 (Fig. 5c, Table 2). In contrast, on day 8, the grazing mortality rates for almost all eukaryotic phytoplanktonic groups studied showed an opposite trend, with values higher by $46-156 \%$ in the warmed treatment 


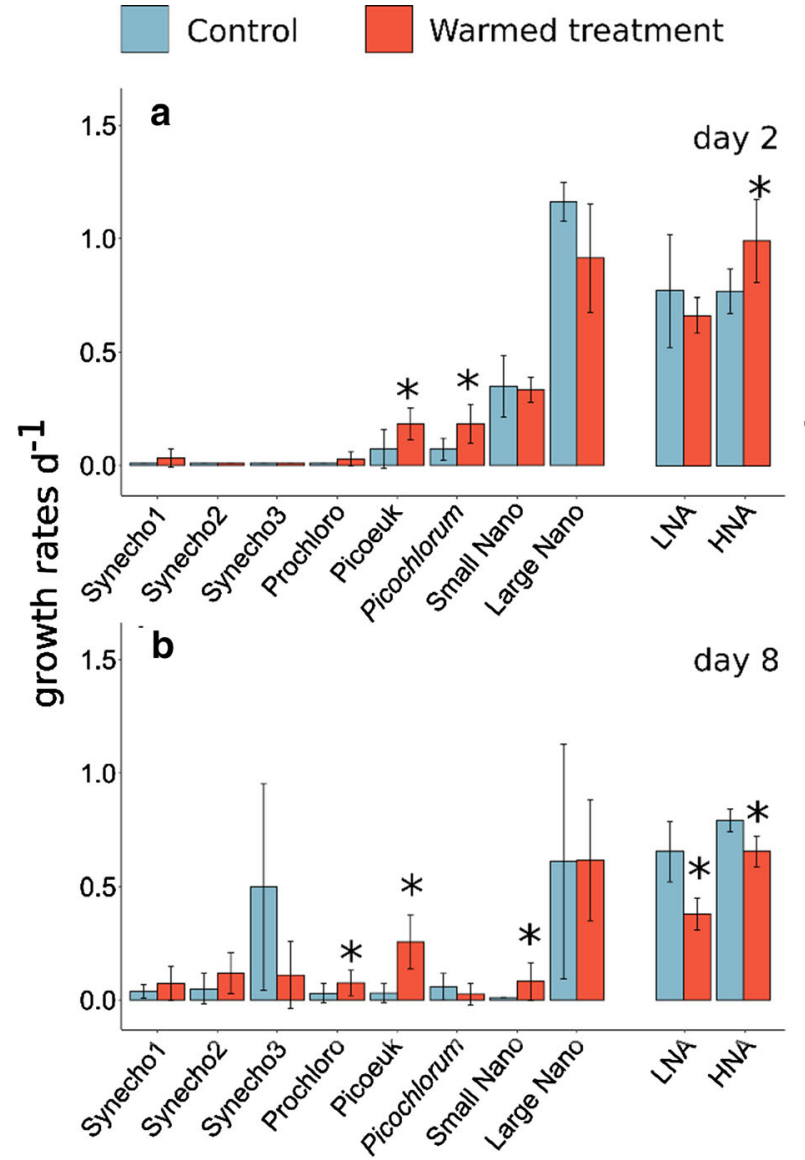

Fig. 5 Determination on day 2 and day 8 of the mean growth rates $\left(\mathrm{d}^{-1} ; \mathbf{a}, \mathbf{b}\right)$ and grazing rates $\left(\mathrm{d}^{-1} ; \mathbf{c}, \mathbf{d}\right)$ for phytoplankton and bacterial groups in the control (blue) and warmed treatment (red) according to the dilution method. The error bars represent

than in the control and this difference being significant for Picoeuk (Fig. 5d, Table 2).

\section{Discussion}

An unexpected autumnal plankton community in Thau Lagoon

This study shows that the phytoplankton community investigated in October 2018 was quite different from what is usually expected at this season in Thau Lagoon. For instance, in the present study, the Chl$a$ concentration, ranging from 2.90 to $5.19 \mu \mathrm{g} \mathrm{dm}^{-3}$, was higher than what was previously reported in October in Thau Lagoon, ranging from 0.61 to $3.55 \mu \mathrm{g} \mathrm{dm}^{-3}$ (Pecqueur et al. 2011; Mostajir et al.

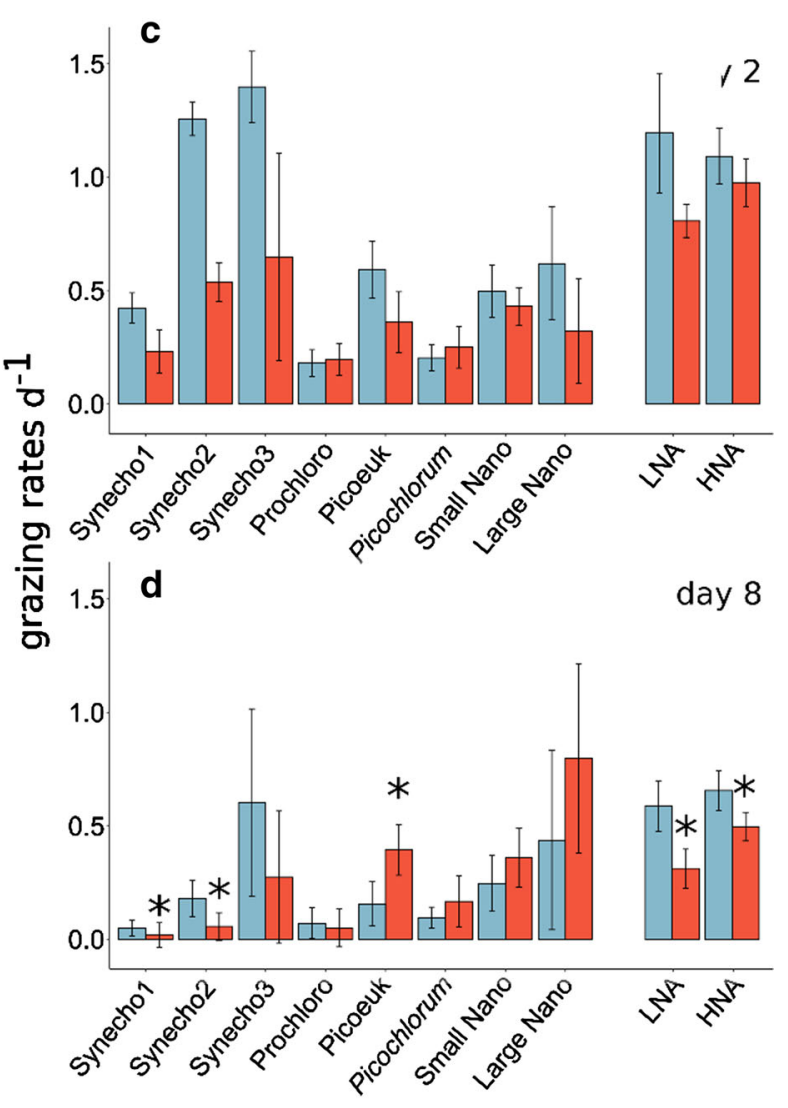

standard deviations from the means. *When the mean rate estimated in the warmed treatment is significantly different from that in the control treatment (Kruskal-Wallis $p<0.05$ )

2015b; Trottet et al. 2016; Fouilland et al. 2017). These higher Chl- $a$ concentrations were surprising considering the fact that the nutrient concentrations measured in the present investigation were within the range as those reported in previous works in October in Thau Lagoon (Pecqueur et al. 2011; Mostajir et al. 2015b; Trottet et al. 2016; Fouilland et al. 2017). Nonetheless, these high Chl- $a$ concentrations observed during the present autumnal study were similar to what was recently reported during winter and spring phytoplankton blooms in Thau Lagoon (Trombetta et al. 2019). However, the fact that the dynamic of Chl- $a$ concentration observed in the present study was flat despite high values was quite unusual for the study site, suggesting peculiar conditions more similar to a dysfunctional situation leading to Chl- $a$ accumulation than to a seasonal bloom. The 
Table 2 Summary of the growth and grazing rates and in parentheses the $p$ values from the KruskalWallis test for the comparison between the control and warmed treatments $p$ values $\leq 0.05$ were considered significant and are highlighted in bold characters

The symbol (-) indicates undetermined $p$ values, which were obtained when tests were not considered relevant or could not be computed

\begin{tabular}{|c|c|c|c|c|c|c|c|}
\hline \multirow{3}{*}{ Day 2} & \multirow{3}{*}{$\begin{array}{l}\text { Cell group } \\
\text { Synecho1 }\end{array}$} & \multicolumn{3}{|c|}{ Growth rates $\left(\mathrm{d}^{-1}\right)$} & \multicolumn{3}{|c|}{ Grazing rates $\left(\mathrm{d}^{-1}\right)$} \\
\hline & & \multirow{2}{*}{$\begin{array}{l}\text { Control } \\
0.01\end{array}$} & \multicolumn{2}{|c|}{ Warmed treatment } & \multirow{2}{*}{$\begin{array}{l}\text { Control } \\
0.42\end{array}$} & \multicolumn{2}{|c|}{ Warmed treatment } \\
\hline & & & 0.03 & $(0.07)$ & & 0.23 & $(<0.001)$ \\
\hline & Synecho2 & 0.01 & 0.01 & $(-)$ & 1.3 & 0.54 & $(<0.001)$ \\
\hline & Synecho3 & 0.01 & 0.01 & $(-)$ & 1.4 & 0.65 & $\left(3.0 \times 10^{-3}\right)$ \\
\hline & Prochloro & 0.01 & 0.03 & $(0.07)$ & 0.18 & 0.2 & $(0.57)$ \\
\hline & Picoeuk & 0.07 & 0.18 & $(\mathbf{0 . 0 1})$ & 0.59 & 0.36 & $\left(3.0 \times 10^{-3}\right)$ \\
\hline & Picochlorum & 0.07 & 0.18 & $\left(5.0 \times 10^{-3}\right)$ & 0.2 & 0.25 & $(0.23)$ \\
\hline & Small Nano & 0.35 & 0.33 & $(0.90)$ & 0.5 & 0.43 & $(0.10)$ \\
\hline & Large Nano & 1.16 & 0.91 & $(0.06)$ & 0.62 & 0.32 & $(0.08)$ \\
\hline & LNA & 0.77 & 0.66 & $(\mathbf{0 . 0 1})$ & 1.19 & 0.81 & $(<0.001)$ \\
\hline & HNA & 0.77 & 0.99 & $(0.57)$ & 1.09 & 0.97 & $(0.06)$ \\
\hline \multirow[t]{10}{*}{ Day 8} & Synecho1 & 0.04 & 0.07 & $(0.40)$ & 0.05 & 0.02 & $(0.02)$ \\
\hline & Synecho2 & 0.05 & 0.12 & $(0.09)$ & 0.18 & 0.06 & $\left(4.0 \times 10^{-3}\right)$ \\
\hline & Synecho3 & 0.5 & 0.11 & $(0.08)$ & 0.6 & 0.27 & $(0.08)$ \\
\hline & Prochloro & 0.03 & 0.08 & $(\mathbf{0 . 0 5})$ & 0.07 & 0.05 & $(0.39)$ \\
\hline & Picoeuk & 0.03 & 0.26 & $\left(1.0 \times 10^{-3}\right)$ & 0.16 & 0.39 & $\left(2.0 \times 10^{-3}\right)$ \\
\hline & Picochlorum & 0.06 & 0.03 & $(0.11)$ & 0.10 & 0.17 & $(0.07)$ \\
\hline & Small Nano & 0.01 & 0.08 & $(\mathbf{0 . 0 2})$ & 0.25 & 0.36 & $(0.10)$ \\
\hline & Large Nano & 0.61 & 0.62 & $(0.75)$ & 0.44 & 0.8 & $(0.14)$ \\
\hline & LNA & 0.65 & 0.38 & $\left(1.0 \times 10^{-3}\right)$ & 0.59 & 0.31 & $\left(1.0 \times 10^{-3}\right)$ \\
\hline & HNA & 0.79 & 0.65 & $(<0.001)$ & 0.65 & 0.5 & $\left(1.0 \times 10^{-3}\right)$ \\
\hline
\end{tabular}

main potential reason that could explain these unusual Chl- $a$ concentrations was related to the in situ picophytoplankton community which was unexpected for Thau Lagoon.

First, Synechococcus-like cells in this study reached exceptionally high abundances $\left(2.4( \pm 1.2) \times 10^{5}\right.$ cells $\mathrm{cm}^{-3}$ on average), approximately 480 times higher than the average abundance reported in fall in a previous study $\left(0.5 \times 10^{3}\right.$ cells $\mathrm{cm}^{-3}$, Bec et al. 2005) and were approximately 30 times higher than the maximal abundance of $8.0 \times 10^{3}$ cells $\mathrm{cm}^{-3}$ reported in the lagoon by Bec et al. (2005) and Collos et al. (2009). Such high abundances have only been reported three other times before in Thau Lagoon, as exceptional events in 2003, in 2006 and, more recently, in 2018 (Derolez et al. 2020a). It appears that these high
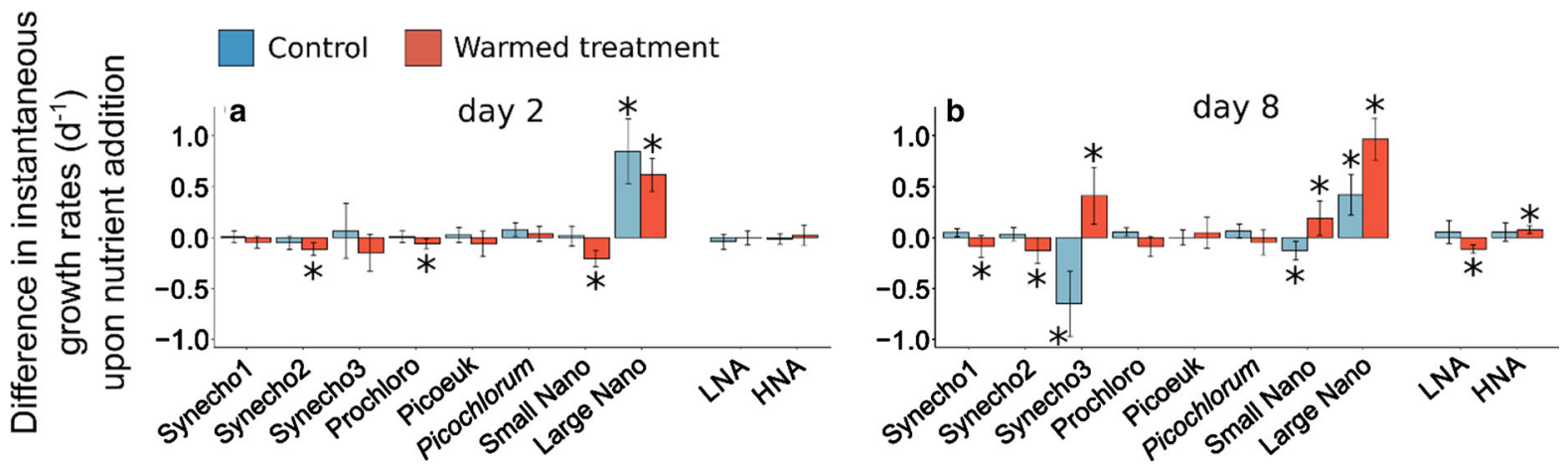

Fig. 6 Determination on day 2 and day 8 of the difference in phytoplankton and bacteria instantaneous growth rates upon nutrient addition, in the control (blue) and warmed treatment (red). The error bars represent standard deviations from the means. *Significant change in the instantaneous growth rate upon nutrient addition (Kruskal-Wallis $p<0.05$ ) 
abundances of picocyanobacteria were concurrent with relatively warm years, suggesting that warming in Thau Lagoon naturally favours picocyanobacteria (Trombetta et al. 2019; Derolez et al. 2020a). It should be noted that at the very beginning of the experiment, the Synechococus-like abundance declined accordingly to the low growth and high grazing rates estimated on day 2. The low growth of Synechococcus-like may appear contradictory with their high abundance observed in the present study. However, the sharp decrease in Synechococcus-like abundances followed by a bloom for Synecho1 might indicate that the balance between their growth and losses can change rapidly. In addition, these changes in the balance between growth and grazing rates over the course of the experiment were difficult to track due to the dilution experiment frequency applied.

Second, the cytometric analyses of cyanobacteria also revealed Prochlorococcus-like cells, a genus that, to our knowledge, had never been reported in Thau Lagoon during the past 20 years (Bec et al. 2005; Collos et al. 2009; Trombetta et al. 2019; Derolez et al. 2020a). Nevertheless, the Prochlorococcus genus present in the Mediterranean Sea could potentially drift into the lagoon via the channels connecting it to the sea. In the present investigation, cyanobacteria were the most abundant but also the most diverse phytoplankton group studied with FCM, as they account for three groups of Synechococcus-like and one group of Prochlorococcus-like genus.

Third, another picoeukaryote taxon that has never been reported in Thau Lagoon before was observed: the genus Picochlorum (Fig. 1), which belongs to the Trebouxiophyceae class (Foflonker et al. 2016). The abundance of Picochlorum, which we observed for the first time in our mesocosm experiment in October 2018, exponentially increased in the lagoon a few weeks later, leading to an ecological and socioeconomic crisis called the "Green Waters". While this "Green Waters" crisis related to Picochlorum in Thau Lagoon has not yet been described in the literature, a quite similar crisis due to an extensive bloom of nontoxic microalgae identified as Nannochloris was reported in the Salses-Leucate Lagoon in the same region and near Thau Lagoon in 1979-1980 (Boutière et al. 1982).

In the present study, nanophytoplankton were also more abundant (ranging from approximately $2.0-16.0 \times 10^{3}$ cells $\mathrm{cm}^{-3}$ ) than what was previously reported by Bec et al. (2005) in October at the same location (50-100 cells $\left.\mathrm{cm}^{-3}\right)$, but remains in the same range of nanophytoplankton abundances reported over the year (Vaquer et al. 1996; Trombetta et al. 2019).

The other plankton cytometric groups, namely, Picoeuk, HNA, LNA, as well as the two virus groups have been commonly reported in previous studies performed in Thau Lagoon and with a similar range of abundances in October (Bec et al. 2005; Mostajir et al. 2015b) as in the present study.

Nanophytoplankton, cyanobacteria, bacteria and virus abundances increased under warming in fall

There is growing evidence that the plankton community response to warming represents a complex combination of individual and common responses. One of the objectives of the present investigation was to experimentally elucidate how an increase in water temperature affects the metabolic rates and shapes the dynamics of the planktonic community in fall.

One of the main results of the present study was that warming slightly but significantly increased the abundances of most cyanobacteria. Moreover, numerous studies have similarly reported a positive correlation between cyanobacteria abundance and temperature (Maugendre et al. 2015; Chen and Laws 2017; Trombetta et al. 2019), even during a fall bloom in the St. Lawrence Estuary (Bénard et al. 2018). In addition, previous studies have reported higher abundances of pico- and nanophytoplankton under warmer temperatures (Pulina et al. 2016; Trombetta et al. 2019). In the present investigation, this trend was also observed for nanophytoplankton over the course of the experiment, but not for picoeukaryotes.

Higher cyanobacteria and nanophytoplankton abundances, especially towards the end of the experiment under warming, resulted in the assimilation of more nutrients, likely causing the lower nutrient concentrations observed in the warmed treatment relative to those in the control. This result highlights that both groups could experience growth even in low nutrient conditions in fall and under warming, suggesting a potential competitive advantage of these groups in warm and nutrient-poor waters (Agawin et al. 2000; Daufresne et al. 2009). In addition, the similarity between the trend of Chl- $a$ concentrations under warming at the end of the experiment and those 
of cyanobacteria and nanophytoplankon underlines that these two groups can be major contributors to the total phytoplankton biomass.

Among the phytoplankton groups, only the abundance of Picochlorum decreased under warming, coinciding with the trend observed for Chl- $a$ concentrations at the middle of the experiment. This highlights the fact that the decrease in Chl- $a$ concentration is likely due to the decrease in Picochlorum abundances. As Picochlorum was observed here for the first time in Thau Lagoon, it was not possible to compare the present results with previous studies from the same location. However, some studies investigating a cultured strain of Picochlorum identified its thermotolerance, which is up to $35{ }^{\circ} \mathrm{C}$ (de la Vega et al. 2011; Foflonker et al. 2016), exceeding by far the average of $25{ }^{\circ} \mathrm{C}$ reached in the warmed mesocosms in the present work. However, this high thermotolerance of Picochlorum was evaluated under optimal nutrient and light conditions. Within a natural plankton assemblage, on the other hand, biotic factors such as predation, infection and competition, which can be affected by an increase in the water temperature, could decrease Picochlorum abundance. For instance, stronger grazing triggered by warming, as reported in the literature (Rose et al. 2009; Vidussi et al. 2011), could depress Picochlorum abundances. Indeed, the grazing rates estimated for Picochlorum tended to increase under warming, suggesting that its predators, benefitting from warmer conditions directly or indirectly through trophic cascades, constituted a main driver of Picochlorum abundances under warming. Alternatively, the higher viral abundances in the warmed treatment, potentially accompanied by higher viral infection and mortality rates among plankton, suggest that viruses could also play a role in the decrease in Picochlorum abundance under warming. Finally, increased competition with other phytoplankton groups could also regulate its abundance under warming. In particular, the cyanobacteria that were found to increase in abundance under warming during the present study and are known to be strong competitors in warm and low-nutrient waters (Bec et al. 2011; Chen and Laws 2017) are potential competitors of Picochlorum under warmed conditions. In regard to the "Green Waters" ecological crisis provoked by Picochlorum, considering that its abundance began to rise in the lagoon at the end of October, Picochlorum potentially benefitted from the colder season to outcompete other phytoplankton. This corroborates the hypothesis that Picochlorum is under weaker control of its population in colder than warmer waters, at least in Thau Lagoon.

The elevation of water temperature in the warmed treatment also resulted in a bloom of picophytoplankton (Synecho1 and Picoeuk) a few days earlier than that in the control, as was also reported in previous studies describing earlier spring (Vidussi et al. 2011) and fall blooms (Bénard et al. 2018) under experimental warming. The significantly stronger increase in the Synecho1 and Picoeuk abundances during the bloom under warming, however, was followed by a significantly stronger decrease in abundance immediately after the bloom. This result indicates that warming also amplified the changes in picophytoplankton abundances and thus their dynamics over time.

The responses of HNA and LNA to elevated temperature were comparable to those of the phytoplankton groups. LNA abundance slightly but significantly increased under warming in the present study, similar to the results of previous studies indicating a positive correlation between LNA abundance and temperature (Morán et al. 2015). HNA abundance, on the other hand, displayed a dynamic comparable to that of the Synechococcus-like bloom (Synecho1), with an increase in abundance followed by a decrease, suggesting a tight coupling with this Synechococcuslike group dynamic. In addition, this increase in HNA abundance also occurred a few days earlier under warming than in the control, highlighting that temperature also drives changes in HNA abundance. However, these results contrast with those from a previous study performed during spring in Thau Lagoon with an identical experimental warming procedure (Vidussi et al. 2011), which reported that warming led to lower bacterial abundances. While these authors suggested that stronger grazing could explain these lower bacterial abundances, we found instead lower grazing rates on bacteria under warming, highlighting that the factor driving bacterial abundance under experimental warming differed from spring to fall in this lagoon, or because initial conditions were different.

Finally, viruses were also more abundant in the warmer treatment than in the control; thus, the possibility of an increase in viral lysis under warming cannot be excluded. Viral lysis has been reported to 
contribute to $10-50 \%$ of bacterial mortality in some regions (Fuhrman 1999; Ory et al. 2010). However, considering the generally slightly higher microbial abundances reported in the current study, viral lysis was not a main driver of the phytoplankton $(<10 \mu \mathrm{m})$ and bacterial populations under warming, except potentially for Picochlorum. These results also contrast with those from the study by Vidussi et al. (2011), as they reported no significant effect of warming on virus abundance during the spring. This could suggest that viruses differently affect the plankton communities in Thau Lagoon in spring than in this study in fall.

Warming in fall promotes phytoplankton and depresses bacterial growth

Warming enhanced the growth rates of most phytoplankton groups according to the results of the two dilution experiments performed on days 2 and 8 of the mesocosm experiment. This trend was less pronounced at the beginning of the experiment, when the warming exposure time was too short to cause a strong effect. In contrast, higher growth rates of phytoplankton after a longer time of exposure to warming were observed on day 8 , in accordance with the literature (Eppley 1972; Savage et al. 2004). The addition of inorganic nutrients revealed that Large Nano growth rates were potentially limited by inorganic nutrients in both treatments on days 2 and 8 . However, on day 8, Small Nano and Synecho3 were also limited by nutrients, but only in the warmed treatment, indicating a potential stronger nutrient limitation effect under warming. These results suggest that the growth rates of some phytoplankton groups in the absence of nutrient limitation could be even more enhanced under warming. This corroborates the competitive advantage observed in some cyanobacteria and nanophytoplankton in terms of growth under warming despite low nutrient concentrations.

Several previous studies have reported a positive correlation between bacterial growth and temperature (White et al. 1991; Huete-Stauffer et al. 2016). However, and surprisingly, the warming in the present study had contrasting effects on bacterial growth rates. HNA growth under warming was significantly increased on day 2, but then both bacterial group growth rates were significantly reduced under warming on day 8 . The former of these two results is in line with those from a study by Huete-Stauffer et al. (2015) describing some cases of bacterial growth decrease under warmed conditions, suggesting that temperature does not always enhance bacterial metabolic rates. The HNA growth rate was potentially limited by inorganic nutrients under warming, as the instantaneous growth rate of this group increased under nutrient addition on day 8 in the warmed treatment. While bacteria mainly use dissolved organic carbon (DOC) for growth, they also need inorganic nutrients (Kirchman 1994). Therefore, a lack of inorganic nutrients could also affect the bacterial growth rate. However, potential nutrient limitation could explain the decrease in the HNA growth rate under warming, but not that of LNA, as the instantaneous growth rate of the latter group did not increase as a result of nutrient addition. As DOC was not added in the dilution experiment, it was not possible to evaluate whether bacteria, especially LNA, were limited by organic carbon. However, the higher viral abundances observed under warming, which could induce more cell lysis, as well as the stronger grazing on eukaryotes observed in the middle of the experiment in the warmed treatment could provide DOC, as these processes have been described as a source of DOC (Danovaro et al. 2011). Therefore, it seems unlikely that bacteria were limited by DOC under warming. The simultaneous decrease in growth rates of both bacterial groups with the increase in those of some phytoplankton groups observed in the present study might suggest an accentuation in competition among these groups under warming. Competition for resources among bacteria and between bacteria and phytoplankton are commonly described in natural plankton communities (Løvdal et al. 2007; Trombetta et al. 2020), and it was shown that warming can accentuate competition for resources (Goldman and Ryther 1976; Kordas et al. 2011).

Warming decreases grazing on small phytoplankton and bacteria in fall

In the present study, elevating the water temperature by $3{ }^{\circ} \mathrm{C}$ surprisingly significantly decreased the microzooplankton grazing rates on most of the studied phytoplankton and bacteria groups at the beginning of the experiment (day 2). This result highlights the fast response of grazers to the warming treatment and was rather unexpected, as several previous studies reported a positive relationship between microzooplankton 
grazers and temperature (Rose and Caron 2007; Chen et al. 2012). Experimentally elevating the temperature by a few degrees also enhanced grazing on both phytoplankton (Rose et al. 2009) and bacteria (Vázquez-Domínguez et al. 2012). Vidussi et al. (2011) investigated the spring Thau Lagoon plankton community and suggested also that warming enhances grazing on both phytoplankton and bacteria. This significant decrease in microzooplankton grazing on phytoplankton and bacteria under experimental warming suggests that warming had a negative effect on the corresponding grazer metabolism, activity or abundance. As previously mentioned, microzooplankton grazers are usually positively affected by an elevation in temperature (Rose and Caron 2007; Chen et al. 2012); thus, a direct negative effect on their metabolism seems unlikely. However, the lower nitrate concentrations under warming could have reduced the nutritional quality of the preys and thus indirectly decreased grazing rates, as prey quality is a criterion of predators selectivity (Burkill et al. 1987). An alternative possible hypothesis is that warming enhanced grazing by larger zooplankton on the grazers of small phytoplankton and bacteria. This could decrease the microzooplankton abundance and thus release their prey, specifically the cytometric groups, from predation pressure in a cascading manner under warming (Vidussi et al. 2011; Lewandowska et al. 2014). During the middle of the experiment (day 8), however, grazing on prokaryotes was still reduced under warming, but that on eukaryote cells increased. This suggests the occurrence of differences in sensitivity between the grazers of prokaryotes and those of eukaryotes, potentially due to changes in the communities of grazers or predators of eukaryotes in response to warming.

\section{Conclusion}

In the present investigation, several significant effects of warming were reported in relation to microbial community abundances, dynamics, and metabolic rates. Warming induced a change at the base of the microbial community, increasing the abundances of nanophytoplankton, cyanobacteria, bacteria and viruses but not those of the newly found Picochlorum in Thau Lagoon. Phytoplankton growth rates were enhanced under warming, while bacterial growth rates were declined, suggesting different mechanisms of their responses to warming. Grazing rates were generally reduced, suggesting that a trophic cascade was triggered under warming. Despite these changes, warming only had a minor effect on phytoplankton $(<10 \mu \mathrm{m})$ and bacterial carbon biomass, which only increased by $5 \%$ compared to that in the control. Phytoplankton $(<10 \mu \mathrm{m})$ and bacteria also accounted for similar percentages of carbon biomass, 60 and $40 \%$, respectively, in both treatments. Therefore, the fall plankton community appeared to be rather resistant to warming in terms of the balance of biomass between phytoplankton $(<10 \mu \mathrm{m})$ and bacteria, while its functioning in terms of microbial abundance and metabolic rates were affected. These findings also highlight the need for more studies on specific plankton assemblages in different seasons and locations to better understand their response to warming.

Acknowledgements We would like to thank the MEDIMEER crew: David Parin for electronic management, Solenn Soriano and Remy Valdes for the daily sampling and setup of the mesocosms and Florian Voron for nutrient analyses. We also warmly thank Maria Protopapa for her help during the dilution experiments. The cytometric analyses of phytoplankton and bacterial samples was performed using the MARBEC MICROBEX platform. We would like to thank Christophe Salmeron from the SU/CNRS BioPIC Imaging and Cytometry platform of Banyuls-sur-mer Oceanologic Observatory for viral abundances analyses. The mesocosm experiment was part of the project AQUACOSM: Network of Leading European AQUAtic MesoCOSM Facilities Connecting Mountains to Oceans from the Arctic to the Mediterranean funded by the European Union Horizon 2020 Program (H2020/2017-2020), Grant Agreement No. 731065 .

Authors' contributions BM and FV with SM conceived and designed the study and established and managed the in situ mesocosm experiment. DP analysed the virus data and TS participated to the sampling, and data processing of the Chl$a$ concentration. JC performed the dilution experiment, collected and analysed the data for phytoplankton and bacteria, and wrote the original draft of the manuscript. All authors participated to the redaction of the final manuscript.

Funding The mesocosm experiment was partly funded by the European Union Horizon 2020 Program (H2020/2017-2020), Grant Agreement $\mathrm{N}^{\circ}$ 731065, through the project AQUACOSM: Network of Leading European AQUAtic MesoCOSM Facilities Connecting Mountains to Oceans from the Arctic to the Mediterranean.

Availability of data and materials The data and material used in this study can be provided by the authors after requested. 
Code availability Not applicable.

\section{Declaration}

Conflict of interest There are no conflicts of interest to disclose for this study.

Open Access This article is licensed under a Creative Commons Attribution 4.0 International License, which permits use, sharing, adaptation, distribution and reproduction in any medium or format, as long as you give appropriate credit to the original author(s) and the source, provide a link to the Creative Commons licence, and indicate if changes were made. The images or other third party material in this article are included in the article's Creative Commons licence, unless indicated otherwise in a credit line to the material. If material is not included in the article's Creative Commons licence and your intended use is not permitted by statutory regulation or exceeds the permitted use, you will need to obtain permission directly from the copyright holder. To view a copy of this licence, visit http://creativecommons.org/licenses/by/4.0/.

\section{References}

Aberle N, Lengfellner K, Sommer U (2007) Spring bloom succession, grazing impact and herbivore selectivity of ciliate communities in response to winter warming. Oecologia 150:668-681. https://doi.org/10.1007/s00442006-0540-y

Agawin NSR, Duarte CM, Agustí S (2000) Nutrient and temperature control of the contribution of picoplankton to phytoplankton biomass and production. Limnol Oceanogr 45:591-600. https://doi.org/10.4319/lo.2000.45.3.0591

Azam F, Fenchel T, Field JG et al (1983) The ecological role of water-column microbes in the sea. Mar Ecol Prog Ser 10:257-263

Bec B, Husseini-Ratrema J, Collos Y et al (2005) Phytoplankton seasonal dynamics in a Mediterranean coastal lagoon: emphasis on the picoeukaryote community. J Plankton Res 27:881-894. https://doi.org/10.1093/plankt/fbi061

Bec B, Collos Y, Souchu P et al (2011) Distribution of picophytoplankton and nanophytoplankton along an anthropogenic eutrophication gradient in French Mediterranean coastal lagoons. Aquat Microb Ecol 63:29-45. https://doi. org/10.3354/ame01480

Bénard R, Levasseur M, Scarratt M et al (2018) Experimental assessment of the sensitivity of an estuarine phytoplankton fall bloom to acidification and warming. Biogeosciences 15:4883-4904. https://doi.org/10.5194/bg-15-4883-2018

Bertilsson S, Berglund O, Karl DM, Chisholm SW (2003) Elemental composition of marine Prochlorococcus and Synechococcus: implications for the ecological stoichiometry of the sea. Limnol Oceanogr 48:1721-1731. https://doi.org/10.4319/lo.2003.48.5.1721

Boutière H, de Bovée F, Delille D et al (1982) Effet d'une crise dystrophique dans l'etang de Salses-Leucate. Oceanol Acta SP:231-242
Brown JH, Gillooly JF, Allen AP et al (2004) Toward a metabolic theory of ecology. Ecology 85:1771-1789. https:// doi.org/10.1890/03-9000

Brussaard CPD (2004) Optimization of procedures for counting viruses by flow cytometry. Appl Environ Microbiol 70:1506-1513. https://doi.org/10.1128/AEM.70.3.15061513.2004

Burkill PH, Mantoura RFC, Llewellyn CA, Owens NJP (1987) Microzooplankton grazing and selectivity of phytoplankton in coastal waters. Mar Biol 93:581-590. https://doi.org/ 10.1007/BF00392796

Calbet A, Landry MR (2004) Phytoplankton growth, microzooplankton grazing, and carbon cycling in marine systems. Limnol Oceanogr 49:51-57. https://doi.org/10.4319/ lo.2004.49.1.0051

Chen B (2015) Assessing the accuracy of the "two-point" dilution technique. Limnol Oceanogr Methods 13:521-526. https://doi.org/10.1002/lom3.10044

Chen B, Laws EA (2017) Is there a difference of temperature sensitivity between marine phytoplankton and heterotrophs? Limnol Oceanogr 62:806-817. https://doi.org/10. 1002/lno. 10462

Chen B, Landry MR, Huang B, Liu H (2012) Does warming enhance the effect of microzooplankton grazing on marine phytoplankton in the ocean? Limnol Oceanogr 57:519-526. https://doi.org/10.4319/1o.2012.57.2.0519

Chisholm SW (2017) Prochlorococcus. Curr Biol 27:R447R448. https://doi.org/10.1016/j.cub.2017.02.043

Collos Y, Bec B, Jauzein C et al (2009) Oligotrophication and emergence of picocyanobacteria and a toxic dinoflagellate in Thau lagoon, southern France. J Sea Res 61:68-75. https://doi.org/10.1016/j.seares.2008.05.008

Danovaro R, Corinaldesi C, Dell'Anno A et al (2011) Marine viruses and global climate change. FEMS Microbiol Rev 35:993-1034. https://doi.org/10.1111/j.1574-6976.2010. 00258.x

Daufresne M, Lengfellner K, Sommer U (2009) Global warming benefits the small in aquatic ecosystems. Proc Natl Acad Sci 106:12788-12793. https://doi.org/10.1073/pnas. 0902080106

de la Vega M, Díaz E, Vila M, León R (2011) Isolation of a new strain of Picochlorum $\mathrm{sp}$ and characterization of its potential biotechnological applications. Biotechnol Prog 27:1535-1543. https://doi.org/10.1002/btpr.686

Derolez V, Malet N, Fiandrino A et al (2020a) Fifty years of ecological changes: Regime shifts and drivers in a coastal Mediterranean lagoon during oligotrophication. Sci Total Environ 732:139292. https://doi.org/10.1016/j.scitotenv. 2020.139292

Derolez V, Soudant D, Malet N et al (2020b) Two decades of oligotrophication: evidence for a phytoplankton community shift in the coastal lagoon of Thau (Mediterranean Sea, France). Estuar Coast Shelf Sci 241:106810. https://doi. org/10.1016/j.ecss.2020.106810

Eppley RW (1972) Temperature and phytoplankton growth in the sea. Fish Bull 70:1063-1085

Foflonker F, Ananyev G, Qiu H et al (2016) The unexpected extremophile: tolerance to fluctuating salinity in the green alga Picochlorum. Algal Res 16:465-472. https://doi.org/ 10.1016/j.algal.2016.04.003 
Fouilland E, Trottet A, Alves-de-Souza C et al (2017) Significant change in marine plankton structure and carbon production after the addition of river water in a mesocosm experiment. Microb Ecol 74:289-301. https://doi.org/10. 1007/s00248-017-0962-6

Fuhrman JA (1999) Marine viruses and their biogeochemical and ecological effects. Nature 399:541-548. https://doi. org/10.1038/21119

Giorgi F (2006) Climate change hot-spots. Geophys Res Lett 33:L08707. https://doi.org/10.1029/2006GL025734

Goldman JC, Ryther JH (1976) Temperature-influenced species competition in mass cultures of marine phytoplankton. Biotechnol Bioeng 18:1125-1144. https://doi.org/10.1002/ bit.260180809

Hays GC, Richardson AJ, Robinson C (2005) Climate change and marine plankton. Trends Ecol Evol 20:337-344. https://doi.org/10.1016/j.tree.2005.03.004

Huete-Stauffer TM, Arandia-Gorostidi N, Díaz-Pérez L, Morán XAG (2015) Temperature dependences of growth rates and carrying capacities of marine bacteria depart from metabolic theoretical predictions. FEMS Microbiol Ecol 91:fiv111. https://doi.org/10.1093/femsec/fiv111

Huete-Stauffer TM, Arandia-Gorostidi N, Alonso-Sáez L, Morán XAG (2016) Experimental warming decreases the average size and nucleic acid content of marine bacterial communities. Front Microbiol 7:1-13. https://doi.org/10. 3389/fmicb.2016.00730

IPCC (2007) Climate Change 2007: Synthesis Report. Contribution of Working Groups I, II and III to the Fourth Assessment Report of the Intergovernmental Panel on Climate Change [Core Writing Team, Pachauri RK, Reisinger A (eds)]. IPCC, Geneva

IPCC (2014) Climate Change 2014: Synthesis Report. Contribution of Working Groups I, II and III to the Fifth Assessment Report of the Intergovernmental Panel on Climate Change [Core Writing Team, Pachauri RK, Meyer LA (eds)]. IPCC, Geneva

Kemp PF, Cole JJ, Sherr BF, Sherr EB (1993) Handbook of methods in aquatic microbial ecology. CRC Press, Boca Raton

Kirchman DL (1994) The uptake of inorganic nutrients by heterotrophic bacteria. Microb Ecol 28:255-271. https:// doi.org/10.1007/BF00166816

Kordas RL, Harley CDG, O'Connor MI (2011) Community ecology in a warming world: the influence of temperature on interspecific interactions in marine systems. J Exp Mar Bio Ecol 400:218-226. https://doi.org/10.1016/j.jembe. 2011.02.029

Lam-Hoai T, Rougier C, Lasserre G (1997) Tintinnids and rotifers in a northern Mediterranean coastal lagoon. Structural diversity and function through biomass estimations. Mar Ecol Prog Ser 152:13-25. https://doi.org/10. 3354/meps 152013

Landry MR, Hassett RP (1982) Estimating the grazing impact of marine micro-zooplankton. Mar Biol 67:283-288. https:// doi.org/10.1007/BF00397668

Lejeusne C, Chevaldonné P, Pergent-Martini C et al (2010) Climate change effects on a miniature ocean: the highly diverse, highly impacted Mediterranean Sea. Trends Ecol Evol 25:250-260. https://doi.org/10.1016/j.tree.2009.10. 009
Lewandowska AM, Boyce DG, Hofmann M et al (2014) Effects of sea surface warming on marine plankton. Ecol Lett 17:614-623. https://doi.org/10.1111/ele.12265

Løvdal T, Eichner C, Grossart H-P et al (2007) Competition for inorganic and organic forms of nitrogen and phosphorous between phytoplankton and bacteria during an Emiliania huxleyi spring bloom (PeECE II). Biogeosci Discuss 4:3343-3375. https://doi.org/10.5194/bgd-4-3343-2007

Marie D, Partensky F, Jacquet S, Vaulot D (1997) Enumeration and cell cycle analysis of natural populations of marine picoplankton by flow cytometry using the nucleic acid stain SYBR green I. Appl Environ Microbiol 63:186-193. https://doi.org/10.1128/AEM.63.1.186-193.1997

Maugendre L, Gattuso J-P, Louis J et al (2015) Effect of ocean warming and acidification on a plankton community in the NW Mediterranean Sea. ICES J Mar Sci 72:1744-1755. https://doi.org/10.1093/icesjms/fsu161

Menden-Deuer S, Fredrickson K (2010) Structure-dependent, protistan grazing and its implication for the formation, maintenance and decline of plankton patches. Mar Ecol Prog Ser 420:57-71. https://doi.org/10.3354/meps08855

Morán XAG, Alonso-Sáez L, Nogueira E et al (2015) More, smaller bacteria in response to ocean's warming? Proc R Soc B Biol Sci 282:20150371. https://doi.org/10.1098/ rspb.2015.0371

Mostajir B, Amblard C, Buffan-Dubau E et al (2015a) Microbial food webs in aquatic and terrestrial ecosystems. In: Bertrand J-C, Caumette P, Lebaron P et al (eds) Environmental microbiology: fundamentals and applications. Springer, Dordrecht, pp 485-509

Mostajir B, Roques C, Bouvier C et al (2015b) Microbial food web structural and functional responses to oyster and fish as top predators. Mar Ecol Prog Ser 535:11-27. https://doi. org/10.3354/meps 11429

Nouguier J, Mostajir B, Le Floc'h E, Vidussi F (2007) An automatically operated system for simulating global change temperature and ultraviolet $\mathrm{B}$ radiation increases: application to the study of aquatic ecosystem responses in mesocosm experiments. Limnol Oceanogr Methods 5:269-279. https://doi.org/10.4319/lom.2007.5.269

Ory P, Hartmann HJ, Jude F et al (2010) Pelagic food web patterns: do they modulate virus and nanoflagellate effects on picoplankton during the phytoplankton spring bloom? Environ Microbiol 12:2755-2772. https://doi.org/10.1111/ j.1462-2920.2010.02243.x

Pecqueur D, Vidussi F, Fouilland E et al (2011) Dynamics of microbial planktonic food web components during a river flash flood in a Mediterranean coastal lagoon. Hydrobiologia 673:13-27. https://doi.org/10.1007/s10750-0110745-x

Pomeroy LR (1974) The ocean's food web, a changing paradigm. Bioscience 24:499-504. https://doi.org/10.2307/ 1296885

Pulina S, Brutemark A, Suikkanen S et al (2016) Effects of warming on a Mediterranean phytoplankton community. Web Ecol 16:89-92. https://doi.org/10.5194/we-16-892016

Rabalais NN, Turner RE, Díaz RJ, Justić D (2009) Global change and eutrophication of coastal waters. ICES J Mar Sci 66:1528-1537. https://doi.org/10.1093/icesjms/fsp047 
Rivkin R, Anderson M, Lajzerowicz C (1996) Microbial processes in cold oceans. I. Relationship between temperature and bacterial growth rate. Aquat Microb Ecol 10:243-254. https://doi.org/10.3354/ame010243

Rose JM, Caron DA (2007) Does low temperature constrain the growth rates of heterotrophic protists? Evidence and implications for algal blooms in cold waters. Limnol Oceanogr 52:886-895. https://doi.org/10.4319/lo.2007.52. 2.0886

Rose JM, Feng Y, Gobler CJ et al (2009) Effects of increased pCO2 and temperature on the North Atlantic spring bloom. II. Microzooplankton abundance and grazing. Mar Ecol Prog Ser 388:27-40. https://doi.org/10.3354/meps08134

Savage VM, Gillooly JF, Brown JH et al (2004) Effects of body size and temperature on population growth. Am Nat 163:429-441. https://doi.org/10.1086/381872

Sime-Ngando T, Gosselin M, Roy S, Chanut J (1995) Significance of planktonic ciliated protozoa in the Lower St. Lawrence Estuary: comparison with bacterial, phytoplankton, and particulate organic carbon. Aquat Microb Ecol 9:243-258. https://doi.org/10.3354/ame009243

Strom SL, Fredrickson KA (2008) Intense stratification leads to phytoplankton nutrient limitation and reduced microzooplankton grazing in the southeastern Bering Sea. Deep Res Part II Top Stud Oceanogr 55:1761-1774. https://doi.org/ 10.1016/j.dsr2.2008.04.008

Trombetta T, Vidussi F, Mas S et al (2019) Water temperature drives phytoplankton blooms in coastal waters. PLoS ONE 14:e0214933. https://doi.org/10.1371/journal.pone. 0214933

Trombetta T, Vidussi F, Roques C et al (2020) Marine microbial food web networks during phytoplankton bloom and nonbloom periods: warming favors smaller organism interactions and intensifies trophic cascade. Front Microbiol 11:1-19. https://doi.org/10.3389/fmicb.2020.502336

Trottet A, Leboulanger C, Vidussi F et al (2016) Heterotrophic bacteria show weak competition for nitrogen in
Mediterranean coastal waters (Thau Lagoon) in autumn. Microb Ecol 71:304-314. https://doi.org/10.1007/s00248015-0658-8

Vaquer A, Troussellier M, Courties C, Bibent B (1996) Standing stock and dynamics of picophytoplankton in the Thau Lagoon (northwest Mediterranean coast). Limnol Oceanogr 41:1821-1828. https://doi.org/10.4319/lo.1996.41.8. 1821

Vázquez-Domínguez E, Vaqué D, Gasol J (2012) Temperature effects on the heterotrophic bacteria, heterotrophic nanoflagellates, and microbial top predators of the NW Mediterranean. Aquat Microb Ecol 67:107-121. https:// doi.org/10.3354/ame01583

Vidussi F, Mostajir B, Fouilland E et al (2011) Effects of experimental warming and increased ultraviolet $\mathrm{B}$ radiation on the Mediterranean plankton food web. Limnol Oceanogr 56:206-218. https://doi.org/10.4319/lo.2011.56. 1.0206

White PA, Kalff J, Rasmussen JB, Gasol JM (1991) The effect of temperature and algal biomass on bacterial production and specific growth rate in freshwater and marine habitats. Microb Ecol 21:99-118

Worden AZ, Binder BJ (2003) Application of dilution experiments for measuring growth and mortality rates among Prochlorococcus and Synechococcus populations in oligotrophic environments. Aquat Microb Ecol 30:159-174. https://doi.org/10.3354/ame030159

Zapata M, Rodríguez F, Garrido J (2000) Separation of chlorophylls and carotenoids from marine phytoplankton:a new HPLC method using a reversed phase C8 column and pyridine-containing mobile phases. Mar Ecol Prog Ser 195:29-45. https://doi.org/10.3354/meps 195029

Publisher's Note Springer Nature remains neutral with regard to jurisdictional claims in published maps and institutional affiliations. 